\title{
Effect of Groundwater Flow on Forming Arsenic Contaminated Groundwater in Sonargaon,
}

\section{Bangladesh}

Shinji Nakaya ${ }^{\mathrm{a}}$, Haruyasu Natsume ${ }^{\mathrm{a}}$, Harue Masuda ${ }^{\mathrm{b}}$, Muneki Mitamura ${ }^{\mathrm{b}}$, Dipak Kumar Biswas ${ }^{\mathrm{c}}$, Ashraf A. Seddique ${ }^{\mathrm{d}}$

${ }^{a}$ Department of Civil Engineering, Shinshu University, Nagano, Japan

${ }^{\mathrm{b}}$ Department of Geosciences, Osaka City University, Osaka, Japan

${ }^{c}$ Asian Arsenic Network, Jessore, Bangladesh

${ }^{\mathrm{d}}$ Department of Petroleum and Mining Engineering, Jessore Science and Technology University, Bangladesh

\section{Abstract}

Three-dimensional groundwater flow in Sonargaon, Bangladesh is numerically simulated in order to evaluate the flow paths of As-contaminated drinking groundwater in the Holocene aquifer of the Ganges-Blamaptra-Meghna delta plain over a recent thirty-year period. The model indicates that vertical infiltration of surface groundwater into the shallow Holocene aquifer occurs frequently in the Ganges-Blamaptra-Meghna delta plain. It predicts that the water recharged from ground surface moves approximately $10 \mathrm{~m}$ to $20 \mathrm{~m}$ vertically downward beneath the flood plain, with a gradually increasing horizontal flow, toward the underlying Pleistocene middle mud layer (aquitard). The model also predicts that groundwaters containing highest As concentrations (> $700 \mu \mathrm{g} / \mathrm{L})$ are formed on the vertical groundwater flow paths where surface water recharges the Holocene aquifer and not on the horizontal flow paths. Combining with the groundwater chemistry, reducing groundwater condition is not essential for the As-contaminated groundwater of the studied area in the Ganges delta plain. 


\section{Introduction}

Large-scale natural arsenic groundwater contamination has been a serious problem in numerous

areas of the world, especially in Asian countries. In many cases it has a major impact on potable water. Such contamination is typically associated with elevated $\mathrm{pH}$ in arid or semi-arid areas, or strongly reducing conditions in geologically young sedimentary basins (e.g., Smedley and Kinniburgh, 2002). In the most polluted area, approximately 35 million people in Bangladesh and 6 million in West Bengal, India are exposed to high levels of As (>50 $\mu \mathrm{g} / \mathrm{L})$ in drinking water (Geological Survey and Department of Public Health Engineering, 2001; Smedley and Kinniburgh, 2002; Nath et al., 2008). Elevated levels of groundwater As (> $50 \mu \mathrm{g} / \mathrm{L})$ in this basin occur on a large scale in strongly reducing alluvium-based aquifers at near-neutral $\mathrm{pH}$, and in flat areas with sluggish shallow groundwater flow. The mechanism and triggers of As dissolution from minerals to groundwater has been addressed by extensive research, and the microbial reduction and dissolution hypothesis, in which As enriched Fe-oxyhydroxides/oxides are decomposed and release the As into the aquifer under reducing groundwater conditions, is widely accepted (e.g., Nickson et al., 2000; McArthur et al., 2001; Bhattacharya et al., 2002; Smedley and Kinniburgh, 2002; van Geen et al., 2003, 2004; Horneman et al., 2004; Zheng et al., 2005). In more recent studies, chemical weathering of detrital basic minerals such as biotite in the aquifer, due to the enforced infiltration of surface water, has been suggested as an essential mechanism for releasing As into the aquifer (e.g., 
Seddique et al., 2008; Itai et al., 2008).

In previous studies, it has been well documented that As-contaminated and As-free/less contaminated areas are distributed as patches in close proximity to each other (e.g., Smedley and Kinniburgh,2002; van Geen et al., 2003; Ravencraft et al., 2002; Mitamura et al., 2008; Itai et al., 2008). Numerous researchers previously considered that the highly contaminated As groundwater appeared in stagnant regions of the aquifer and that dissolved As was flushed out of deep aquifers but not from the shallow aquifers, due to low groundwater mobility. Harvey et al. $(2002 ; 2003)$, however, documented that the circulation of local groundwater occurred on a scale of a few hundred meters in diameter, and that such small-scale circulation activated in this thirty-year period promoted As release into the groundwater. These results are considered valuable because it revealed that the groundwater flow system was an essential factor causing As groundwater contamination in the Ganges delta plain (e.g., Geological Survey and Department of Public Health Engineering, 2001; Harvey et al., 2006; Klump et al., 2006; Mukherjee et al., 2007; Michael and Voss, 2009; Neumann et al., 2010; Mukherjee et al., 2011). However, few studies focusing on the relationship between the distribution of varying As contamination levels and groundwater systems have subsequently been published.

By conducting a series of studies in Sonargaon, Bangladesh, we realized that the vertical infiltration of surface water into the shallow aquifer promoted As contamination. In those studies, Mitamura et al. (2008) reported that wells installed into fine sediments were highly contaminated by 
As (highly As-contaminated wells were occasionally installed into fine micaceous sediments), and that the geological structure of the aquifers was an important factor controlling the formation of As-contaminated groundwater in Bangladesh. Seddique et al. (2008) reported that detrital biotite was a primary source of As and that chemical weathering of this mineral was an essential mechanism affecting the chemical composition of groundwater, including the As concentration thereof (Itai et al., 2008). Heterogeneous distribution of major chemical components and the isotopic ratios of oxygen and hydrogen in the groundwaters indicated vertical infiltration of surface groundwater into the shallow sediments and short groundwater recharge paths (Itai et al., 2008). In this study, three-dimensional transient groundwater flow is simulated with realistic assumptions of hydraulic constants and boundary conditions of the geological structure, focusing on the relationship between the flow paths and the concentrations of As in contaminated drinking groundwater over a recent thirty-year period in the shallow groundwater system of the Holocene aquifer.

\section{Method}

Transient three-dimensional groundwater flow was simulated using a numerical model to document the flow paths and the residence time of As-contaminated groundwater in the Holocene aquifer of the study area over thirty years. The model was constructed based on a data set including topography; geological structure; hydraulic constants; tube well information (numbers, locations 
and screen depths of wells drilled less than $40 \mathrm{~m}$ deep that are used mainly for drinking water); the population living at each levee where there are settlements; transient water head records for three observation wells installed at three different depths at the same site; temporal groundwater level records at eight hand-auger drilling sites; irrigation; precipitation; evapotranspiration; and assumed boundary conditions of aquifers surveyed in 2003 through 2006. The ground surface of all study area can be recharge area and the river zone can be recharge or discharge area depending on hydraulic gradient between river water head and groundwater head. Of the data used in this study, the temporal groundwater level changes and geochemical characteristics such as major and minor compositions, $\mathrm{H}, \mathrm{O}, \mathrm{N}$ and $\mathrm{S}$ isotopes, tritium units, etc., were already published in the previous reports (Mitamura et al., 2008; Itai et al., 2008).

\section{Site description and hydrogeological setting}

The study area is $3.0 \mathrm{~km} \times 3.0 \mathrm{~km}$ in size, located $20 \mathrm{~km}$ east of Dhaka, in Sonargaon, Bangladesh. The area is composed of terraces in the west and a flood plain, including natural levees along the old Brahmaputra River, which is an abandoned channel of the present Meghna River. Except for the natural levees, the flood plain is inundated during the rainy season. During the dry season, the floodplain dries and is used for cultivation, and the channel becomes narrower and consists of a series of disconnected ponds (Fig. 1). The flat surface of the ground, which only varies $4 \mathrm{~m}$ to $5 \mathrm{~m}$ in altitude, and the meandering river channel suggest a very low hydraulic 
gradient and/or sluggish groundwater flow beneath the flood plain. Drinking water is drawn from groundwater through tube wells installed into shallow and deep aquifers in the populated western terrace and levees. Aquifers less than $90 \mathrm{~m}$ deep in the study area consist of upper and lower sand formations separated by a mud layer; the upper Holocene sand formation is commonly $25 \mathrm{~m}$ to 35 m thick and overlies the Upper Pleistocene mud formation, which unconformably overlies the lower Plio-Pleistocene sand formation (Mitamura et al., 2008) (Fig. 1). The upper sand formation thus comprises the shallow unconfined aquifer, and the lower formation is the deep confined aquifer. The upper sand formation hosts thin intercalated clay to silt layers in the upper section, and medium sand in the lower section. The upper sand formation can, therefore, be divided into the uppermost sand and the upper sand layers at approximately $0 \mathrm{~m}$ altitude. The mud formation, which functions as an aquitard, also includes intercalated lenses of very fine sand to silt. The lower sand formation is exposed as terraces in the western part of the study area. The upper sand formation thus abuts the lower sand formation with an inferred fault along the boundary between the terraces and the alluvial flood plain. The mud and lower sand layers are partly eroded to form valleys in this area.

\section{Model description}

Three-dimensional groundwater flow in unsaturated-saturated porous media is modeled by the governing equation as follows:

$$
\frac{\partial}{\partial x_{i}}\left[K_{\mathrm{r}}(\theta) K_{i j} \frac{\partial \varphi}{\partial x_{j}}+K_{\mathrm{r}}(\theta) K_{i 3}\right]+q=\left(C(\theta)+\alpha S_{\mathrm{s}}\right) \frac{\partial \varphi}{\partial t} ; i, j=1,2,3
$$


where $\varphi$ is hydraulic head, $x_{i}$ is a spatial coordinate, $t$ is time, $K_{i j}$ is the saturated hydraulic conductivity, $\theta$ is the volumetric water content $\left(=n S_{\mathrm{r}}\right), n$ is porosity, $S_{\mathrm{r}}$ is the saturation index (ranging from 0 to 1 ), $K_{\mathrm{r}}(\theta)$ is the unsaturated-saturated hydraulic conductivity ratio (also ranging from 0 to 1$), C(\theta)$ is the specific water content $(=\mathrm{d} \theta / \mathrm{d} \varphi), S_{\mathrm{s}}$ is the specific storage, and $\alpha$ is a function with a value of 1 when $S_{\mathrm{r}}=1$ and 0 when $S_{\mathrm{r}}<1$.

Equation (1) is solved for unknown $\varphi$ under appropriate boundary conditions. In the present study, because unsaturated-saturated seepage flow including rain, evaporation and irrigation recharge in unconfined aquifer is analyzed, the unsaturated-saturated three-dimensional seepage flow analysis code AC-UNSAF3D (developed by Okayama University, Japan in 1980s and opened as a standard code since 2000 in Japan: http://gw.civil.okayama-u.ac.jp/gel_home/download/index.html) was applied with a three- dimensional finite element method (3D-FEM) scheme (Segol, 1977; Frind and Verge, 1978; Huyakorn et al., 1986; Nishigaki et al., 1992) to document the three-dimensional groundwater flow in this study area using a one month time step. This code is specified for advective flow only.

\section{Model of stratigraphic structure and hydraulic properties}

In the present FEM model, a region $3500 \mathrm{~m}$ in the $x$ direction, $3000 \mathrm{~m}$ in the $y$ direction and $114 \mathrm{~m}$ in the vertical $(z)$ direction is divided into 106567 rectangular voxels of $100 \mathrm{~m} \times 100 \mathrm{~m} \times \Delta z$

[m] (Table 1). Because a rectangular grid system with small $\Delta \mathrm{z} / \Delta \mathrm{x}$ and $\Delta \mathrm{z} / \Delta \mathrm{y}$ ranging from 
$5 \times 10^{-3}$ to $2 \times 10^{-2}$ was adopted, FEM was used instead of finite difference method from the point of analytical precision. The length in the $\mathrm{x}$ direction $(3500 \mathrm{~m})$ was extended $500 \mathrm{~m}$ eastward from the study area to avoid boundary effects. Elements above the ground surface are excluded from the model. To construct the model, the hydrogeological structure of the area is divided into three layers; the upper sand formation, of which the uppermost S1 and S2 layers were defined from sediment particle size, the lower sand formation S3, and the mud formation $\mathrm{M}$, which functions as an aquitard separating the upper and lower sand formations. The coordinates $(x, y, z)$ of the boundary between the aquifers and aquitard are defined based on lithostratigraphic data (Mitamura et al., 2008) of sediment columns at 12 drilling sites by linear interpolation using the Surfer code (Golden Software, Inc.) considering well depth of the 230 tube wells. For evaluating the volume of well water withdrawn, well depths are assumed to be the same as the screen depths of the 230 tube wells we studied. Figure 2 shows the contour map of the ground surface from SRTM 90 m digital elevation data originally produced by NASA and the estimated geological structures. Depressions or buried valleys, which partly eroded the mud formation, appeared as two WNW-ESE furrows and an intermittent NNE-SSW furrow beneath the flood plain. One of the furrows along the WNW-ESE direction, which includes drill site DRK-D1 (Figs. 1 and 2(e)) lacks the middle mud formation, and the upper and lower sand formations connect directly.

Hydraulic properties determined by in situ pumping tests (Mitamura et al., 2008) were assigned to each element of the model according to the boundary surfaces between S1, S2, S3, and M (Table 
2). The hydraulic constants of aquitard $\mathrm{M}$, the specific storage $S_{\mathrm{s}}$, and the nonlinear hydraulic properties of suction potential ( $\varphi-\theta$ relationship) and hydraulic conductivity ( $K_{\mathrm{r}}-\theta$ relationship) for each sedimentary formation are defined without hysteresis in the wetting and drying curves in the unsaturated zone of the aquifers (Bear, 1972; Marsily, 1986; Huyakorn et al., 1986; Nishigaki et al., 1992). If an element of the model is divided by the layer boundary surfaces, weighted average values of the hydraulic constants are assigned to the element according to the volume occupied by each aquifer or aquitard.

\section{Simulation conditions}

Under the hydrogeological setting described above, groundwater flow in the FEM model was primarily determined for a thirty-year period simulating the conditions associated with temporal changes in the level of the water table; precipitation, evapotranspiration, and groundwater pumping rates for daily use and irrigation. The rate of groundwater pumping for daily use was estimated based on data gathered in 2005 on the number of families, population, number of tube wells, and well screen depth in each village (Table 3). The average monthly precipitation during 2005 in Bangladesh (Fig. 3) was assigned to the nodal points on the ground surface. The floodwater table on the flood plain along the old Brahmaputra River was assigned to nodal points on the ground surface, set to vary with temporal changes of the groundwater potential observed in 2005 in the shallow aquifer (upper sand formation) in wells DRK-W2 (-18 $\mathrm{m}$ to $-27 \mathrm{~m}$ ) and DRK-W3 (-6 m to -12 m) 
(Fig. 4). The monthly evapotranspiration (Fig. 5) was assigned to nodal points on the ground surface estimated from the average monthly temperature between 1957 and 1987 at the Rangamati meteorological observatory $\left(22.63^{\circ} \mathrm{N}, 92.20^{\circ} \mathrm{E}, 63 \mathrm{~m}\right.$ above sea level (ASL)), Bangladesh, using the Thornthwaite equation (Thornthwaite, 1948). Fresh water withdrawal for domestic use in

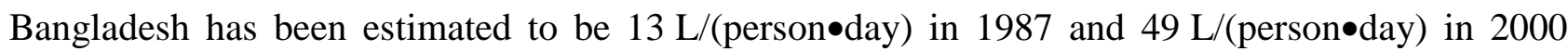
(The World's Water; http://www.worldwater.org/data.html). $100 \mathrm{~L} /$ day/person was assumed as a maximum value for recent withdrawals from the tube wells based on these figures. The Bangladesh Rehabilitation Assistance Committee Office in Narayanganj, Bangladesh estimated well water usage of $4 \mathrm{~L} /($ person`day) for this area (pers comm.). Thus, a constant pumping rate of either

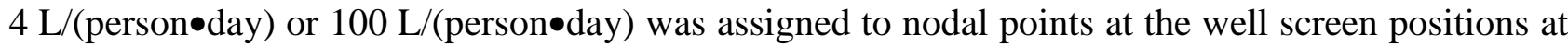
$5 \mathrm{~m}$ vertical intervals. The volume withdrawn from each well was calculated from the pumping rate, local population, and numbers of tube wells, with flow percentages attributed to each well in each village by depth (Table 3). Withdrawal of groundwater from the deep aquifer and recharge via its distribution as much as the withdrawal onto the ground surface for irrigation during the dry season were also taken into account in the numerical simulation using data for the 2003-2004 irrigation season (January to April) in Munshiganj, Bangladesh (Harvey et al., 2006). The withdrawal from the deep aquifer for seasonal irrigation (January to April) as much as the $\alpha$ percent of the withdrawal $\left(\mathrm{Q}_{\mathrm{w}}\right)$ given by Harvey et al. (2006) (Fig. 3) and the seasonal recharge promoted by irrigation as much as the $\alpha$ percent of the $\mathrm{Q}_{\mathrm{w}}$ were assigned to the nodal points at $\mathrm{z}=-70 \mathrm{~m}$ ASL 
beneath the flood plain and at the ground surface, excluding levees, respectively, for the period from January to April. In the present study, $\alpha$ was determined to be $75 \%$ in the calibration by trial and error as described in the chapter 'Result'. The volume of irrigation water taken from the deep aquifer is much greater than that withdrawn for drinking water in this area; the water recharged due to irrigation during the dry season is a maximum of $45 \mathrm{~mm} / \mathrm{month}$ (The World's Water; http://www.worldwater.org/data.html). The boundary conditions of inflow rate and potential head at the ground surface nodes for the thirty modeled years were, therefore, controlled by monthly changes in precipitation, evapotranspiration, irrigation groundwater recharge and the level of the water table. As described before, horizontal groundwater flow direction will be macroscopically from north to south and horizontal hydraulic gradient will be very low due to the flat surface and the meandering river channel. Considering the temporally large changes of groundwater head at wells and river water head in delta plain, the synchronically systematic potential head difference between upstream and downstream must cause constant, horizontal groundwater flow. However, it is difficult to obtain the hydrological data on the macroscopic, horizontal groundwater flow from upstream to downstream using the only data within this study area. To consider the groundwater flow from upstream to downstream, constant inflow and outflow rates were estimated to be the flow rates equivalent to a hydraulic gradient of $1 \mathrm{~m} / 10,000 \mathrm{~m}$. The rates were estimated from synchronically systematic potential head differences between $3.6 \mathrm{~m}$ and $7.7 \mathrm{~m}$ in this study area and $1.5 \mathrm{~m}$ and $5.7 \mathrm{~m}$ in Munshiganj (Harvey et al., 2006), and were assigned to the saturated nodal 
points on the north and the south vertical boundary faces, respectively. The transient three-dimensional groundwater flow analysis was carried out by a month as a time step.

\section{Results}

First, calibration or sensitivity analyses were carried out by checking the concordance between calculated and observed results shown in Figures 6 and 7 to indicate the applicability of the simulation model. Figures 6(a) and 6(b) show the numerically simulated groundwater head for the 1st to 15 th years (a) and 16th to 30th years (b) in the 30-year simulation of wells DRK-W1,

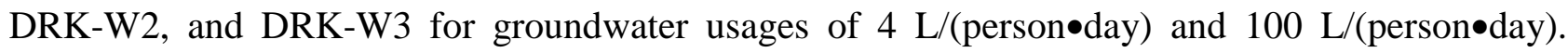
Figures 6(c) and 6(d) show the variation of simulated groundwater head in the 30th year for the 4

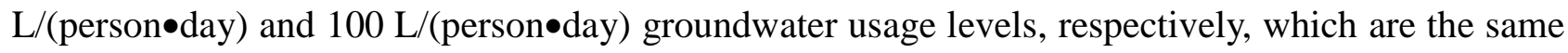
as the simulations of the 2nd to 29th years of the thirty-year simulation (Figs. 6 (a) and 6(b)) at wells DRK-W1, DRK-W2, and DRK-W3 (Fig. 1). In Fig. 3, the irrigation rate is reduced to 75 percent of the initial value given by Harvey et al. (2006). The groundwater head variations obtained are consistent with observed values to within $0.4 \mathrm{~m}$. When omitting pumping for irrigation, the computed groundwater heads in both the shallow (S1 and S2) and deep (S3) aquifers give the same temporal variation, and the difference between the observed and calculated groundwater heads is 1 $\mathrm{m}$ to $1.5 \mathrm{~m}$ in the late dry to early rainy seasons from January to June. It is clear that the uptake of groundwater for irrigation causes the groundwater head in the deep aquifer to be lower than in the 
shallow aquifers in the dry season. The volume of groundwater withdrawn from tube wells for daily use (4 L/(person॰day) or $100 \mathrm{~L} /($ person॰day) does not affect the groundwater head throughout the year, suggesting that pumping from the tube wells has a negligible effect on the groundwater flow regimen in the study area. The simulated annual variation pattern of the groundwater head did not change for 29 years, from the second year of the simulation, suggesting a recurrent hydrological cycle in the area. Stability of the simulation results under the present assumptions and boundary conditions are also confirmed from the periodicity for those 29 years. Figure 7 shows a map of unconfined groundwater head computed for October, early in the dry season, with the observed levels at eight hand-auger drilling sites in early October, 2006. Despite uncertainties in the hydrologic data, the spatial variation of simulated groundwater heads are concordant with the observed levels, indicating that the model used here appropriately simulates the groundwater flow regimen for this study area.

Figure 8 shows simulated monthly horizontal groundwater flow velocities at $Z=-10 \mathrm{~m}$ from January to December. The horizontal groundwater flow differs markedly between the dry and rainy seasons. In the dry season, from January to May, the dominant groundwater flow in the shallow aquifer (S2) is around and toward a WNW-ESE furrow in the southeastern part of the study area, where the middle mud formation is thin or non-existent (Fig. 2(e)). The groundwater flows from the shallow aquifer into the deep aquifer by contact between the aquifer sediments due to the lack of the middle mud formation (Figs. 8(a) to (e) and 2(e)), indicating that irrigation pumping affects the 
groundwater flow in the dry season. Between July and September in the rainy season, horizontal flow is limited beneath the flood plain, and its dominant pattern appears to be radial flow from the levees to surrounding areas (Figs. $8(\mathrm{~g})$, (h) and (i)). Thus the low horizontal hydraulic gradient of the region increases the extent of stagnant conditions in the aquifer during the period of annual flooding. The radial groundwater flow, typically in actively recharge zones, is produced by the positive groundwater potential of the large rainy season precipitation to raise the water table of the shallow aquifer. The village of Harihardi (Fig. 1) is such an active recharge zone. From October to November, early in the dry season, the stagnant zones become small, and the velocity of the radial flow increases (Figs. 8(j) and (k)). In June and December, the groundwater flow changes between the dry and rainy season patterns (Figs. 8(f) and (1)). The simulation also shows slight groundwater flows from the terrace into the deep aquifer (S3) beneath the flood plain in both dry and rainy seasons.

To evaluate the groundwater residence, the groundwater flow path toward the tube well was traced by forward and backward particle tracking of the particle source placed at an arbitrary point, assuming advection of hypothetical, non-reactive particle (e.g., Mukherjee et al., 2011) using spatiotemporal distribution of the flow velocities computed by the three-dimensional groundwater flow analysis. Figures 9(a) to 9(f) show the modeled groundwater flow paths toward the location of tube wells Nos. 1 through 6 at $Z=5,0,-5,-10,-15,-20,-25,-30 \mathrm{~m}$. Water recharged from the ground surface infiltrates between $5 \mathrm{~m}$ and $20 \mathrm{~m}$ vertically downward, with its horizontal flow 
component increasing with depth, toward the drilled hole. The groundwater flow path toward the well becomes longer and the horizontal component becomes larger with increasing depth. Figure $9(\mathrm{~g})$ shows the relationship between $\mathrm{z}$ and residence time (model age) $\left(\mathrm{T}_{\mathrm{R}}\right)$ calculated for the wells Nos. 1 through 6. In this study, the residence time (model age) means the time required for particle to reach the target point from a recharge point. Although the simulation is limited to a thirty year run, the obtained model age can be longer than thirty years because the model age can be calculated from the sum of $T_{R}$ on arbitrary segments along the groundwater flow path. The model age of groundwater in the Holocene aquifer increases with depth and is proportional to depth down to approximately $-20 \mathrm{~m}$. The correlation between depth, as it increases to about $20 \mathrm{~m}$ below the ground surface, and the model age of the groundwater is concordant with the correlation between the depth and residence time of groundwater estimated from ${ }^{3} \mathrm{H} /{ }^{3} \mathrm{He}$ isotopes in the Holocene aquifers of the Munshiganji District (Klump et al., 2006) and in Araihazar Upazila (Stute et al., 2007).

Figures 10 and 11 demonstrate the simulated groundwater flow paths toward the midpoint of the 5-meter long screen, along with As concentrations for the 126 surveyed tube wells installed in the shallow (Holocene) aquifer (above about -20 m ASL). The present model predicts that vertical infiltration of surface water into the shallow aquifer sediments occurs often; the water recharged from the ground surface (about $4 \mathrm{~m}$ to $10 \mathrm{~m}$ ASL) of the flood plain moves approximately $5 \mathrm{~m}$ to 20 m downward and the groundwater flow gradually changes toward the horizontal direction as it approaches the underlying middle mud layer (aquitard $\mathrm{M}$ ). The drinking water pumped up is 
derived from the groundwater flowing downward from the ground surface toward the tube well. As noted above, recharge and subsequent radial flow appear in and around levees. A stagnant zone appears in the rainy to early dry season, July to October (figs. 7-11), while recharge is promoted in the stagnant zone in the dry season. The model also predicts that the shallow groundwater in the Holocene aquifer will not recharge in the terrace (figs. 10). The areas with the highest As concentrations $(700 \mu \mathrm{g} / \mathrm{L}<$ As $<1200 \mu \mathrm{g} / \mathrm{L})$ and high As concentrations $(500 \mu \mathrm{g} / \mathrm{L}<\mathrm{As}<700$ $\mu \mathrm{g} / \mathrm{L}$ ) correspond to the zones where recharge occurs in the rainy to early dry seasons (Figs. 7, 8 and 10). Thus, local groundwater flow and the As concentration in the flow path must be important for the mechanism that produces As-contaminated groundwater. Figure 12 shows the spatial distribution of As and the concentration of dissolved oxygen (DO), which was measured after attainment of the stabilities of DO, ORP, EC and $\mathrm{pH}$ with enough pumping, of 45 of the total 51 points measured from the end of September to early November in 2009 in eastern levees where an active recharge zone appears. DO is detected in 20 of the 51 well samples. The most active recharge zone (Figs. 8, 10 and 11) in this study area appears in the village of Harihardi village (Fig. 1), where DO levels of $1.3 \mathrm{mg} / \mathrm{L}$ to $3.3 \mathrm{mg} / \mathrm{L}$ were detected in 18 of the 28 wells. Two well samples containing fairly amounts of DO $(1.73$ and $1.76 \mathrm{mg} / \mathrm{L})$ relative to $\mathrm{DO}(0 \mathrm{mg} / \mathrm{L})$ in reducing condition were among the seven that had As $>500 \mu \mathrm{g} / \mathrm{L}$.

Figure 13 shows computational results presenting the relationship between the average length of the groundwater flow path (Lp) and the average residence time (model age) $\left(T_{R}\right)$ from the ground 
surface to tube wells, with the As concentration of each well's water, excluding three wells that had residence times >30 years $(920 \mathrm{~m}, 38.5$ years, $351 \mathrm{As} \mu \mathrm{g} / \mathrm{L}),(367 \mathrm{~m}, 43$ yeas, $146 \mathrm{As} \mu \mathrm{g} / \mathrm{L})$ and (532 m, 31 years, $75 \mathrm{As} \mu \mathrm{g} / \mathrm{L}$ ). The estimated Lp ranges from $38 \mathrm{~m}$ to $920 \mathrm{~m}$, and $\mathrm{T}_{\mathrm{R}}$ ranges from 4 years to 43 years. The $T_{R}$ obtained here is concordant with the estimation that the Holocene aquifer (Mitamura et al., 2008) hosts groundwater recharged after 1953 based on ${ }^{3} \mathrm{H}$ measurements of this study area (Itai et al., 2008). Groundwaters in the As hotspots (> $700 \mu \mathrm{g} / \mathrm{L}$ ) are characterized by short flow paths and residence times; the hotspots with the highest As concentrations $(>700 \mu \mathrm{g} / \mathrm{L})$ have flow paths shorter than $220 \mathrm{~m}$ and residence times (model ages) $<10$ years.

\section{Discussion}

Here, the As contamination process is discussed in relation to simulated flow paths for a recent thirty-year period in the Holocene aquifer. As noted above, shallow groundwater in the Holocene aquifer has a downward flow path from the ground surface toward each tube well. The sources of that groundwater are rivers, local rainwater, and a small contribution of deeper groundwater distributed on the cultivation field for the irrigation. As groundwater hotspots in this area are closely related to the groundwater flow path after the recharge: our simulation shows that the among the wells we studied As hotspots appear in wells having relatively short $L p$ and $T_{R}$ as shown in Fig. 13. Figure 14 shows two conceptual models, A (CM-A), in which the As is released mainly during vertical groundwater infiltration, and $\mathrm{B}(\mathrm{CM}-\mathrm{B})$ in which the As is released over the entire flow 
path where As is concentrated in the aquifer sediments. Through the groundwater flow, advection, dispersion and reactive transport of As often occur. In case CM-A (Fig. 14(a)), the As released in the vertical flow path would be diluted by the ambient horizontally flowing groundwater. Even if the groundwater passes through As-rich sediment, little As is released. Therefore, As hot spots appear close to the recharge zones in places where the groundwater has short flow paths and residence times. This model can explain the relationship between the $T_{R}$ and the $L p$ of the groundwaters in the Holocene aquifer shown in Fig. 13. The linear correlation between groundwater age determined using ${ }^{3} \mathrm{H} /{ }^{3} \mathrm{He}$, at depths $<20 \mathrm{~m}$ and the dissolved As concentration was observed in Araihazar Upazila (Stute et al., 2007). These authors also found that the age of groundwaters containing the highest As concentrations $>1100 \mu \mathrm{g} / \mathrm{L}$ (hotspots) are considerably younger than the others, of which ages are plotted on the linear regression line. Thus, the considerable As release in Araihazar Upazila would occur in the vertical flow path through As-rich sediments, which are distributed as patches, similar to our model CM-A. In case CM-B (Fig. 14(b)), As is not only released in the vertical flow path, but also in the following horizontal path. According to this model, high As concentrations in the groundwater appear to be independent of the length of the flow path and residence time. Therefore, case CM-B cannot explain the As hotspots of this study area. We conclude that the release of As from the Holocene aquifer in our study area is likely to occur primarily in vertically infiltrating water. Arsenic contaminated groundwater in Asian countries is typically found under two different groundwater conditions (e.g., Smedley and Kinningurgh, 2002); 
i.e., reducing conditions in humid climates, such as Bangladesh, Vietnam, etc., and oxic conditions in arid to semi-arid climates, such as Pakistan and Mongolia. The formation mechanism in reducing groundwater is believed to be microbial reduction and decomposition of Fe-oxyhydroxides, releasing As, which is adsorbed onto the Fe-oxyhydroxides (e.g., Nickson et al., 2000; Horneman et al., 2004; van Geen et al., 2004; Zheng et al., 2004; Mukherjee et al., 2008). The As release in the oxic groundwater is explained by desorption of As from Fe-oxyhydroxides without decomposition (e.g., Amini et al., 2008). According to these hypotheses, the As in the groundwater of the oxic recharge zone in the study area is likely released via desorption from Fe-oxyhydroxides without decomposition. Some researchers propose silicates as sources of the As; e.g., biotite has been considered to be a primary source (Seddique et al., 2008), although chlorite was demonstrated to enrich As in Masuda et al. (2010). Such basic minerals are easily decomposed via chemical weathering, which is promoted by water flow irrespective of the redox condition, although an oxic condition is preferable to an anoxic condition. In our study area, redox condition of the Holocene groundwaters allows to precipitate $\mathrm{FeOOH}$ (goethite) and $\mathrm{Fe}(\mathrm{OH})_{3}$ (ferrihydrite) (Itai et al., 2008). They also documented that the chemical weathering of detrital minerals such as plagioclase and basic minerals are important factors to form chemical composition of the groundwaters. If chemical weathering of As-bearing mineral(s) is the case, higher As concentrations can be expected in the rather oxic recharge zone where the groundwater flow rate is higher than that in the stagnant anoxic zone. This study cannot specify the As contamination mechanism at present, but it is clear that a 
reducing groundwater condition is not essential to form As contaminated groundwater of the study area, and presumably even for the other As contaminated groundwater in the Ganges delta plain.

\section{Acknowledgements}

The authors would like to thank anonymous reviewers, Associate Editor and Dr Laurent Charlet for constructive reviews and helpful comments. We would like to thank Dr Kazi Matin Ahmed for assistance and support on the field survey. We would also like to thank Ataur Rahman (BRAC) for additional information of well and population for each village in the study area. This research was partly supported by a Grant-in-aid for Science Research, number 15403017, from the Japanese Ministry of Education, Science, Sports and Culture.

\section{References}

Amini M., Abbaspour, K. C., Berg, M., Winkel, L., Hug, S. J., Hoehn, E., Yang, H., Johnson, C. A., 2008. Statistical Modeling of Global Geogenic Arsenic Contamination in Groundwater. Environ. Sci. Technol., 42 (10), 3669-3675, DOI: 10.1021/es702859e.

Bear, J., 1972. Dynamics of fluids in porous media, American Elsevier Pub. Co., New York.

Bhattacharya, P., Jacks, G., Ahmed, K. M., Routh, J., Khan, A. A., 2002. Arsenic in groundwater of the Bengal Delta Plain Aquifers in Bangladesh. Bull. Environ. Contam. Toxicol., 69, 538-545, DOI: $10.1007 / \mathrm{s} 00128-002-0095-5$. 
British Geological Survey and Department of Public Health Engineering, Arsenic Contamination of Groundwater in Bangladesh, vol. 2, Final Report, BGS Tech. Rep. WC/00/19, edited by D. G. Kinniburgh and P. L. Smedley, Br. Geol. Surv., Keyworth, UK, 2001.

Frind, E. O., Verge, M. J., 1978. Three-dimensional modeling of groundwater flow system. Water Resour. Res., 14(5), 844-856.

Harvey, C. F., Ashfaque, K. N., Yu, W., Badruzzaman, A. B. M., Ali, M. A., Oates, P. M., Michael, H. A., Neumann, R. B., Beckie, R., Islam, S., Ahmed, M. F., 2006. Groundwater dynamics and arseniccontamination in Bangladesh. Chemical Geology, 228, 112-136.

Harvey, C. F., Swartz, C. H., Badruzzaman, A. B. M., Keon-Blute, N., Yu, W., Ali, M. A., et al. 2002. Arsenic mobility and groundwater extraction in Bangladesh. Science 298(5598), $1602-1606$.

Harvey, C. F., Swartz, C. H., Badruzzaman, A. B. M., Keon-Blute, N., Yu, W., Ali, M. A., et al. 2003. Response to comments on "Arsenic mobility and groundwater extraction in Bangladesh". Science 300(5619), 584.

Horneman, A., van Geen, A., Kent, D. V., Mathe, P. E., Dhar, R. K., O'Cinekk, S., Hoque, M. A., Aziz, Z., Shamsudduha, M., Seddique, A. A. Ahmed, K. M., 2004. Decoupling of As and Fe release to Bangladesh groundwater under reducing conditions. Part I: Evidence from sediment profiles. Geochim. Cosmocim. Acta, 68(17), 3459-3473.

Huyakorn, P. S., Springer, E. P., Guvanasen, V., Wadsworth, T. D., 1986. A three dimensional 
finite-element model for simulating water flow in variably saturated porous media. Water Resour. Res., 22(13), 1790-1808.

Itai, T., Masuda, H., Seddique, A.A., Mitamura, M., Maruoka, T., Li, X., Kusakabe, M., Dipak, B.K., Farooqui, A., Yamanaka, T., Nakaya, S., Matsuda, J., Ahmed, K.M., 2008. Hydrological and geochemical constraints on the mechanism of formation of arsenic contaminated groundwater in Sonargaon, Bangladesh. Appl. Geochem. 23, 3155-3176.

Klump, S., Kipfer, R., Cirpka, O. A., Harvey, C. F., Brennwald, M. S., Ashfaque, K. N., Baduruzzaman, A. M., Hug, S. H., Imboden, D. M., 2006. Groundwater dynamics and arsenic mobilization in Bangladesh assessed using noble gases and tritium. Environ. Sci. Technol. 40, 243-250.

Masuda, H., Shinoda, K., Noguchi, N., Okudaira, T., Takahashi, Y., Mitamura, M., Seddique, A.A., 2010. Chlorite as a primary source of arsenic in groundwater aquifer sediments in Bengal delta. Geochim. Cosmochim. Acta 74 (12S1), A676.

McArthur, J. M., Ravencroft, P., Safiullah, S., Thirlwall, M. F., 2001. Arsenic in groundwater: Testing pollution mechanisms for sedimentary aquifers in Bangladesh. Water Resour. Res., 37(1), 109-117.

Michael H. M., Voss C. I., 2009. Controls on groundwater flow in the Bengal Basin of India and Bangladesh: regional modeling analysis. Hydrogeology Journal, 17, 1561-1577, doi 10.1007/s10040-008-0429-4. 
Mitamura, M., Masuda, H., Itai, T., Minowa, T., Maruola, T., Ahmed K. M., Seddique, A. A. Dipak, B. K., Nakaya, S., Li, X. D., Uesugi, K., Kusakabe, M., 2008. Geological structure of an arsenic-contaminated aquifer at Sonargaon, Bangladesh. J. Geology, 116, 288-302.

Mukherjee, A., Fryar, A. E., Howell, P. D., 2007. Regional hydrostratigraphy and groundwater flow modeling in the arsenic-affected areas of the western Bengal basin, West Bengal, India, Hydrogeology Journal, 15, 1397-1418, doi 10.1007/s10040-007-0208-7.

Mukherjee, A., Fryar, A. E., Scanlon, B. R.,Bhattacharya, P., Bhattacharya, A., 2011. Elevated arsenic in deeper groundwater of the western Bengal basin, India: Extent and controls from regional to local scale, Appl. Geochem., 26(4), 600-613.

Mukherjee, A., von Brömssen, M., Scanlon, B. R., Bhattacharya, P., Fryar, A. E., Hasan, M. A., Ahmed, K. M., Chatterjee, D., Jacks, G., Sracek, O., 2008. Hydrogeochemical comparison and effects of overlapping redox zones on groundwater arsenic near the Western (Bhagirathi sub-basin, India) and Eastern (Meghna sub-basin, Bangladesh) margins of the Bengal Basin, J. Contaminant Hydrology, 99, 31-48, doi:10.1016/j.jconhyd. 2007.10.005.

Nath, B., Stüben, D., Basu Mallik, S., Chatterjee, D., Charlet, L., 2008. Mobility of arsenic in West Bengal aquifers conducting low and high groundwater arsenic, part I: comparative hydrochemical and hydrogeological characteristics. Appl. Geochem. 23, 977-995.

Nickson, R., McArthur, J. M., Ravenscroft, P, Burgess, W. G., Ahmed K. M., 2000. Mechanism of arsenic release to groundwater, Bangladesh and West Bengal. Appl. Geochem. 15, 403-413. 
Nishigaki, M., Nakaya, S., Kono, I., 1992. A three dimensional finite element method for seepage through a saturated/unsaturated porous media by using SSOR-PCG method (Japanese with English abstract). JSCE, III-19(448), 101-110.

Neumann, R.B., Ashfaque, K.N., Badruzzaman, A.B.M., Ali, M.A., Shoemaker, J.K., Harvey, C.F., 2010. Anthropogenic influences on groundwater arsenic concentrations in Bangladesh. Nature Geosci. 3, 46-52.

Sakellariou-Makrantonaki, M., Tzimopoulos, C., Gouliaras, D., 1987. Analysis of a closed-form analytical model to predict the hydraulic conductivity function. J. Hydrology, 92, 28-300.

Seddique A. A., Masuda, H., Mitamura, M., Shinoda, K., Yamanaka, T., Itai, T., Maruoka, T., Uesugi, K., Ahmed, K. M., Biswas, D. K., 2008. Arsenic release from biotite into a Holocene groundwater aquifer in Bangladesh. Appl. Geochem. 23, 2236-2248.

Segol, G., 1977. A three-dimensional Galerkin-finite element model for the analysis of contaminant transport in saturated-unsaturated porous media. in Finite Elements in Water Resources, edited by W. G. Gray, G. F. Pinder, and C. A. Brebbia, 2123-2144, Pentech, London.

Smedley, P. L., Kinninburgh, D. G., 2002. A review of the source, behavior and distribution of arsenic in natural waters. Appl. Geochem. 17, 517-568.

Stute, M., Zheng, Y., Schlosser, P., Horneman, A., Dhar, R. K., Datta, S., Hoque,M. A., Seddique, A. A., Shamsudduha, M., Ahmed, K. M., van Geen, A, 2007. Hydrological control of As concentrations in Bangladesh groundwater. Water Resour. Res., 43, W09417, 
doi:10.1029/2005WR004499.

Thornthwaite, C.W., 1948. An approach toward a rational classification of climate. Geographical Review, 38, 55-94.

van Geen, A., Rose, J., Thoral, S., Garnier, J. M., Zheng, Y., Bottero, J. Y., 2004. Decoupling of As and Fe release to Bangladesh groundwater under reducing conditions. Part II: Evidence from sediment incubations. Geochim. Cosmochim. Acta 68(17), 3475-3486, doi:10.1016/j.gca.2004.02.014.

van Geen, A., Zheng, Y., Versteeg, R., Stute, M., Horneman, A., Dhar, R., Steckler, M., Gelman, A., Small, C., Ahsan, H., Graziano, J. H., Hussain I., Ahmed, K. M., 2003. Spatial variability of arsenic in 6000 tube wells in a $25 \mathrm{~km}^{2}$ area of Bangladesh. Water Resour. Res. 3(5), 1140, doi:10.1029/2002WR001617.

van Genuchten, M. Th., 1980. A closed-form equation for predicting the hydraulic conductivity of unsaturated soils. Soil Sci. Am. J., 44(5), 892-898.

Zheng, Y., van Geen, A., Stute, M., Dhar, R., Mo, Z., Cheng, Z., Horneman, A., Gavrieli, I., Simpson, H.J., Versteeg, R., Steckler, M., Grazioli-Venier, A., Goodbred, S., Shahnewaz, M., Shamsudduha, M., Hoque, M.A., Ahmed, K.M., 2005. Geochemical and hydrogeological contrasts between shallow and deep aquifers in two villages of Araihazar, Bangladesh: implications for deeper aquifers as drinking water sources. Geochim. Cosmochim. Acta 69(22), $5203-5218$. 
481

Zheng, Y., Stute, M., van Geen, A., Gavrieli, I., Dhar, R., Simpson, H. J., Schlosser, P., Ahmed, K. M., 2004. Redox control of arsenic mobilization in Bangladesh groundwater, Applied Geochemistry, 19, 201-214, doi:10.1016/j.apgeochem.2003.09.007. 


\section{Figure captions}

Figure 1. (a) Sampling wells and drill sites in study area. (b) Sediment columns at twelve drilling sites. (c) Inferred geologic cross section (E-W). (d) Inferred geologic cross section (N-S). Sedimentary layers are divided into upper and lower sand formations, and successive middle mud formation separating between the upper and the lower sand formations. This figure is modified from Mitamura et al. (2008).

Figure 2. Contour maps of the ground surface from SRTM 90m digital elevation data originally produced by NASA (a), base of uppermost sand formation (aquifer 1) (b), base of upper sand formation (aquifer 2) (c), base of middle mud formation (aquitard) (d) and thickness of the middle mud formation (e) estimated from lithostratigraphic data (Figure 1) by linear interpolation.

Figure 3. Average monthly precipitation during 2005 and irrigation in Bangladesh. The averaged precipitation was inferred from the data cited on the web site of Bangladesh Meteorological Department (http://www.bangladeshonline.com/bmd/). The irrigation was obtained from data for the 2003-2004 irrigation season (January to April) in Munshiganj, Bangladesh (Harvey et al., 2006).

Figure 4. Temporal change of the groundwater potential observed at well DRK-W1 in deep aquifer (lower sand formation), and at wells DRK-W2 and W3 in shallow aquifer (upper sand 
formation) in 2005. The screens of observation wells at Darikandi site (Figure 1) were installed in 45 to $54 \mathrm{~m}$ depth (W1), 18 to $27 \mathrm{~m}$ depth (W2), and 6 to $12 \mathrm{~m}$ depth (W3).

Figure 5. Monthly evapo-transpiration estimated from the average monthly temperature between 1957 and 1987 at the Rangamati meteorological observatory $\left(22.63^{\circ} \mathrm{N}, 92.20^{\circ} \mathrm{E}, 63 \mathrm{~m}\right.$ above sea level (ASL)), Bangladesh, using the Thornthwaite equation (Thornthwaite, 1948).

Figure 6. Numerically simulated groundwater head for the 1 st to 15 th year (a) and 16th to 30th years (b) in 30-years simulation of wells DRK-W1, W2, and W3 for groundwater usage of both 4 and $100 \mathrm{~L} /($ person॰day). (c) and (d) show the variation of simulated groundwater head in the 30th

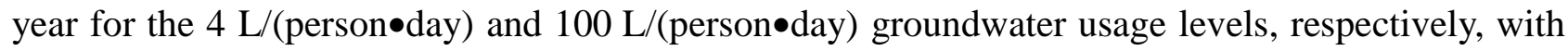
observed values at wells DRK-W1, DRK-W2, and DRK-W3 (Fig. 1). H-Lower and H-upper indicate the observed groundwater heads in lower and upper sand formation, respectively, in 2005. Hcal indicates the simulated groundwater heads.

Figure 7. Contour map of unconfined groundwater head computed for October, early in the dry season, with the observed levels at eight hand-auger drilling sites in early October, 2006.

Figure 8. Horizontal groundwater flow velocities simulated at $\mathrm{Z}=-10 \mathrm{~m}$ in January (a), February (b), 
March (c), April (d), May (e), June (f), July (g), August (h), September (i), October (j), November

(k) and December (1).

Figures 9. Modeled groundwater flow paths toward the location of tube wells Nos. 1 through 6 at $Z=5,0,-5,-10,-15,-20,-25,-30 \mathrm{~m}$ i. e. tube well of Nos. 1 (a), 2 (b), 3 (c), 4(d), 5 (e) and 6 (f). (g) Relationship between $\mathrm{z}$ and residence time (model age) calculated for the wells Nos. 1 through 6.

Figure 10. Simulated groundwater flow paths toward the midpoint of the 5-meter long screen, along with As concentrations for the 126 surveyed tube wells installed in the shallow (Holocene) aquifer (above about -20m ASL). (a) As $<300 \mathrm{mg} / \mathrm{L}$, (b) As $>300 \mathrm{mg} / \mathrm{L}$.

Figure 11. Vertical profile of simulated groundwater flow paths toward the midpoint of the 5-meter long screen, along with As concentrations for the 126 surveyed tube wells installed in the shallow (Holocene) aquifer (above about -20m ASL). (a) x-z plane, (b) y-z plane.

Figure 12. Spatial distribution of As and the concentration of dissolved oxygen (DO) of 45 of the total 51 points measured from the end of September to early November in 2009 in eastern levees where a recharge zone appears. 
Figure 13. Relationship between the average length of the groundwater flow path (Lp) and the average residence time (model age) $\left(T_{R}\right)$ from the ground surface to tube wells, with the As concentration of each well's water, excluding three wells that had residence times $>30$ years $(920 \mathrm{~m}$, 38.5 years, 351 As $\mu \mathrm{g} / \mathrm{L}),(367 \mathrm{~m}, 43$ yeas, $146 \mathrm{As} \mu \mathrm{g} / \mathrm{L})$ and $(532 \mathrm{~m}, 31$ years, $75 \mathrm{As} \mu \mathrm{g} / \mathrm{L})$. V indicates velocity by $\mathrm{Lp} / \mathrm{T}_{\mathrm{R}}$.

Figure 14. (a) Conceptual model A (CM-A) and (b) conceptual model B (CM-B) for As release in the groundwater flow system obtained in this study. 


\section{Tables}

Table 1. Finite Element Size Using in 3D-FEM Analysis.

\begin{tabular}{rrrrrrr}
\hline Depth (m) & & $\Delta \mathrm{x}(\mathrm{m})$ & $\Delta \mathrm{y}(\mathrm{m})$ & \multicolumn{2}{c}{$\Delta \mathrm{z}(\mathrm{m})$} \\
\hline 14 & - & 0 & 100 & 100 & 0.5 \\
0 & - & -70 & 100 & 100 & 1 & \\
-70 & - & -100 & 100 & 100 & 2 \\
\hline
\end{tabular}

Table 2. Hydraulic Properties of Aquifers and Aquitard Using in 3D-FEM Analysis.

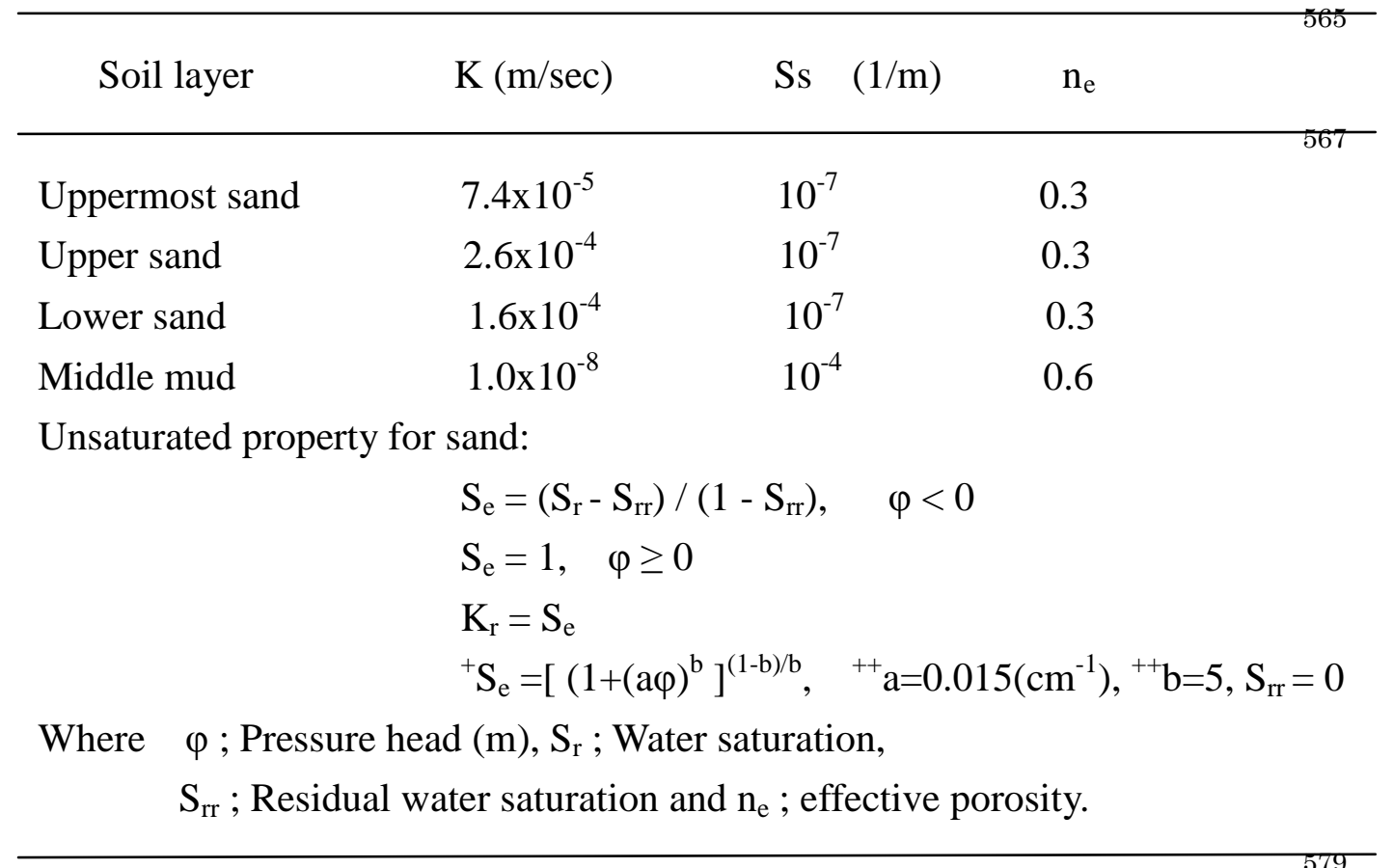

+: van Genuchten (1980),

++: Sakellariou-Makrantonaki et al. (1987) 
Table 3. Survey Data for Each Village of the Study Area in 2005.

\begin{tabular}{|c|c|c|c|c|c|c|c|c|c|}
\hline \multirow[t]{2}{*}{ Village name } & \multirow[t]{2}{*}{ Family } & \multirow[t]{2}{*}{ Population } & \multirow{2}{*}{$\begin{array}{l}\text { Number of } \\
\text { Tube well }\end{array}$} & \multicolumn{6}{|c|}{ Persentage of tube well $(\%) /$ depth } \\
\hline & & & & $-15.24 \mathrm{~m}$ & $\begin{array}{l}15.24 \text { - } \\
30.48 \mathrm{~m}\end{array}$ & $\begin{array}{l}30.48 \text { - } \\
45.72 \mathrm{~m}\end{array}$ & $\begin{array}{l}45.72- \\
60.96 \mathrm{~m}\end{array}$ & $\begin{array}{l}60.96- \\
91.44 \mathrm{~m}\end{array}$ & $91.44 \mathrm{~m}-$ \\
\hline Muchar Char (MCC) & 303 & 2086 & 293 & 0 & 82 & 15 & 0 & 1 & 2 \\
\hline Harihardi (HHD) & 74 & 379 & 73 & 0 & 85 & 9 & 6 & 0 & 0 \\
\hline Darikandi (DKD) & 69 & 364 & 40 & 0 & 88 & 0 & 13 & 0 & 0 \\
\hline Dolardi (DLD) & 169 & 1062 & 109 & 0 & 54 & 41 & 4 & 0 & 0 \\
\hline Kumarchar (KMC) & 113 & 580 & 66 & 0 & 61 & 31 & 6 & 3 & 0 \\
\hline Gankulkandi (GLK) & 65 & 317 & 38 & 0 & 88 & 13 & 0 & 0 & 0 \\
\hline Mamurdi (MMD) & 116 & 631 & 68 & 0 & 97 & 0 & 0 & 3 & 0 \\
\hline Gulnagar (GLG) & 102 & 536 & 74 & 0 & 43 & 43 & 0 & 0 & 0 \\
\hline Atbari (ABA) & 38 & 226 & 19 & 0 & 100 & 0 & 0 & 0 & 0 \\
\hline Bara Kaitargaon (BKB) & 193 & 1216 & 95 & 0 & 73 & 0 & 12 & 15 & 0 \\
\hline Ledamdi (LDD) & 45 & 251 & 26 & 0 & 88 & 0 & 13 & 0 & 0 \\
\hline Temdi (TMD) & 70 & 346 & 41 & 0 & 86 & 0 & 0 & 14 & 0 \\
\hline
\end{tabular}




\section{Fig. 3, Nakaya et al.}

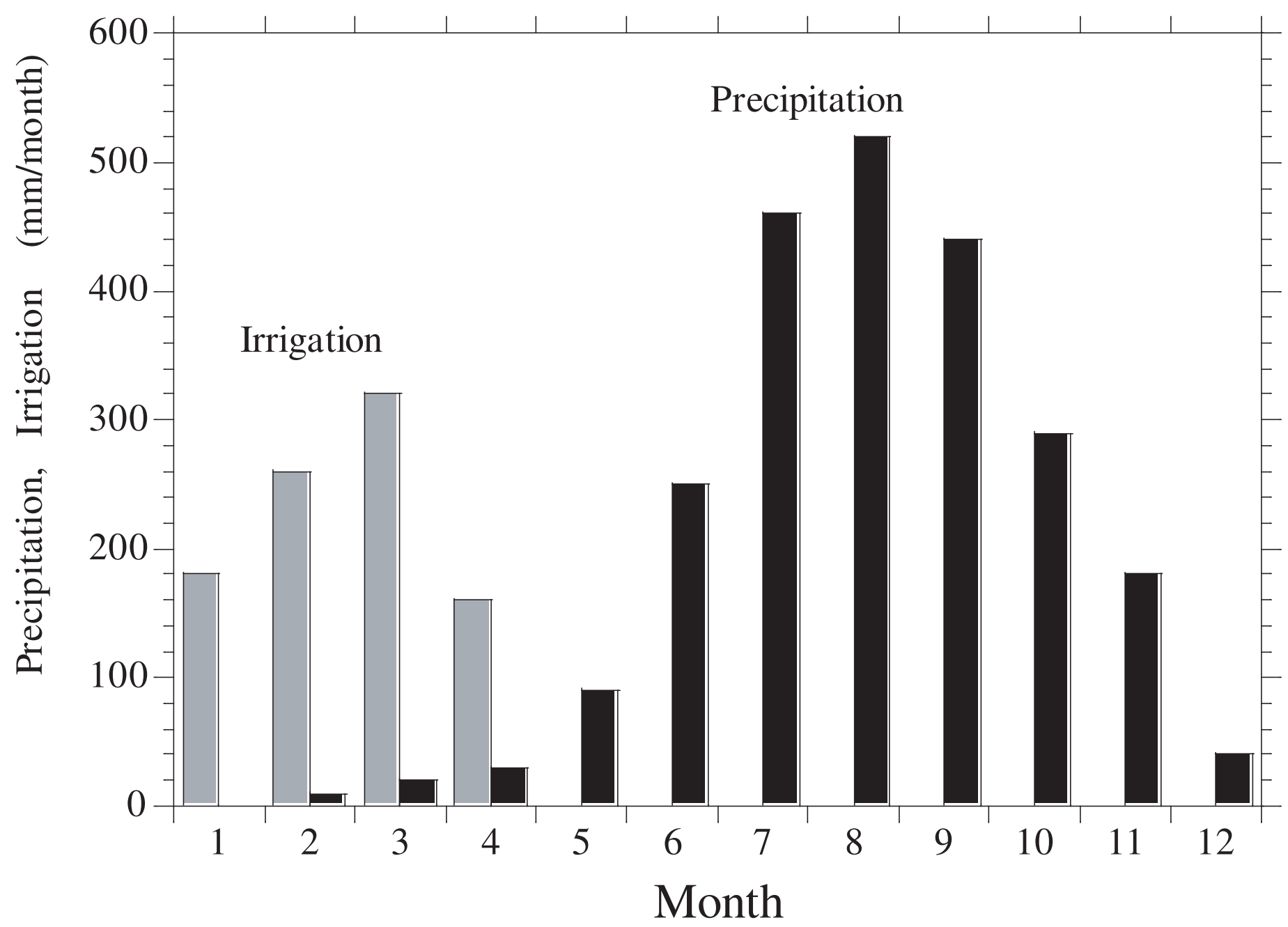

Figure 3.Average monthly precipitation during 2005 and irrigation in Bangladesh. The averaged precipitation was inferred from the data cited on the web site of Bangladesh Meteorological Department (http://www.bangladeshonline.com/bmd/). The irrigation was obtained from data for the 2003-2004 irrigation season (January to April) in Munshiganj, Bangladesh (Harvey et al., 2006). 
Fig. 4, Nakaya et al.

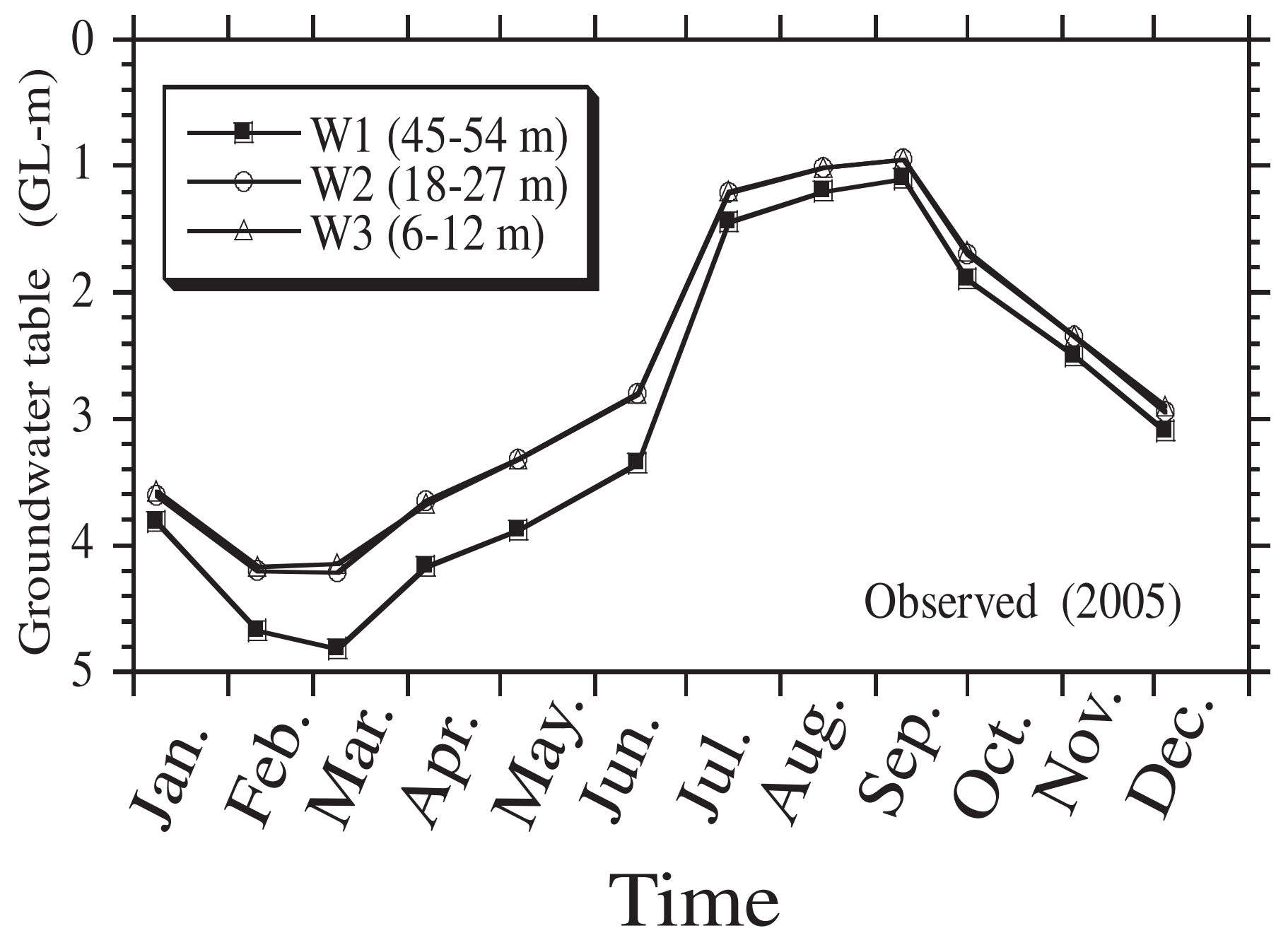

Figure 4. Temporal change of the groundwater potential observed at well DRK-W1 in deep aquifer (lower sand formation), and at wells DRK-W2 and W3 in shallow aquifer (upper sand formation) in 2005. The screens of observation wells at Darikandi site (Figure 1) were installed in 45 to $54 \mathrm{~m}$ depth (W1), 18 to $27 \mathrm{~m}$ depth (W2), and 6 to $12 \mathrm{~m}$ depth (W3). 


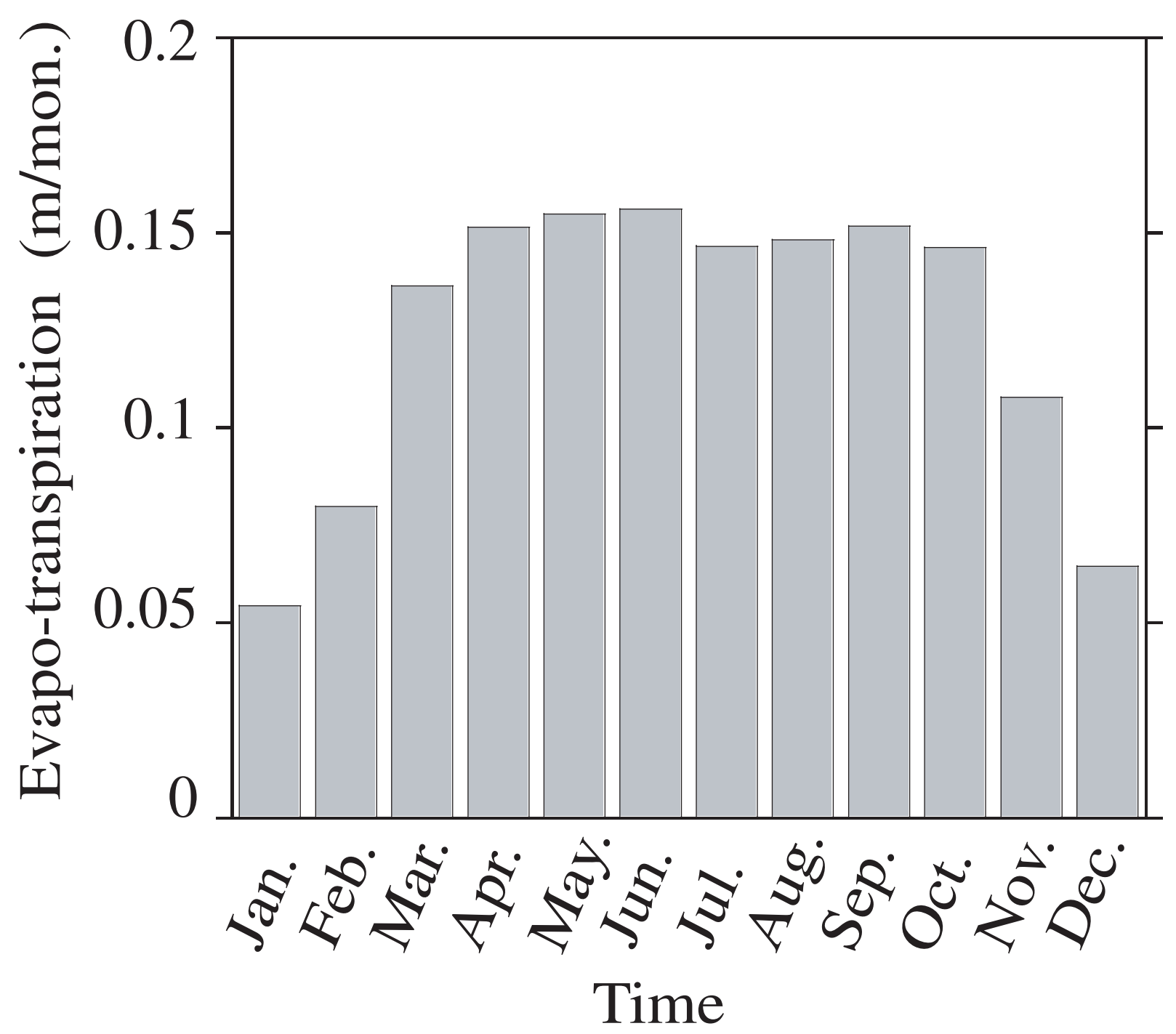

Figure 5. Monthly evapo-transpiration estimated from the average monthly temperature between 1957 and 1987 at the Rangamati meteorological observatory $\left(22.63^{\circ} \mathrm{N}, 92.20^{\circ} \mathrm{E}, 63 \mathrm{~m}\right.$ above sea level (ASL)), Bangladesh, using the Thornthwaite equation (Thornthwaite, 1948). 
Fig. 6, Nakaya et al.
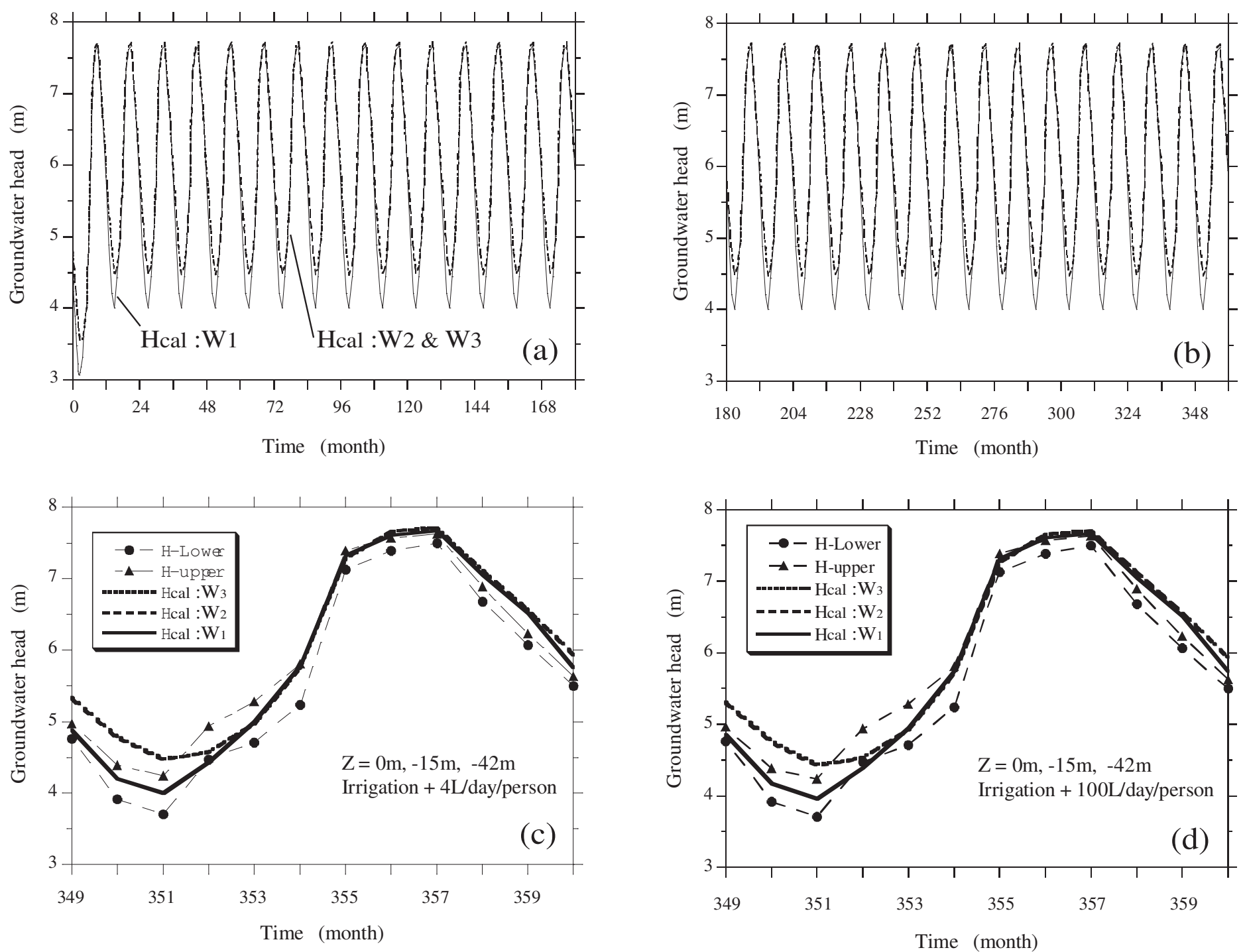

Figure 6. Numerically simulated groundwater head for the 1 st to 15 th year (a) and 16th to 30th years (b) in 30-years simulation of wells DRK-W1, W2, and W3 for groundwater usage of both 4 and 100 $\mathrm{L} /$ (person*day). (c) and (d) show the variation of simulated groundwater head in the 30th year for the 4 $\mathrm{L} /($ person $*$ day) and $100 \mathrm{~L} /($ person$*$ day) groundwater usage levels, respectively, with observed values at wells DRK-W1, DRK-W2, and DRK-W3 (Fig. 1). H-Lower and H-upper indicate the observed groundwater heads in lower and upper sand formation, respectively, in 2005. Hcal indicates the simulated groundwater heads. 
Fig. 7, Nakaya et al.
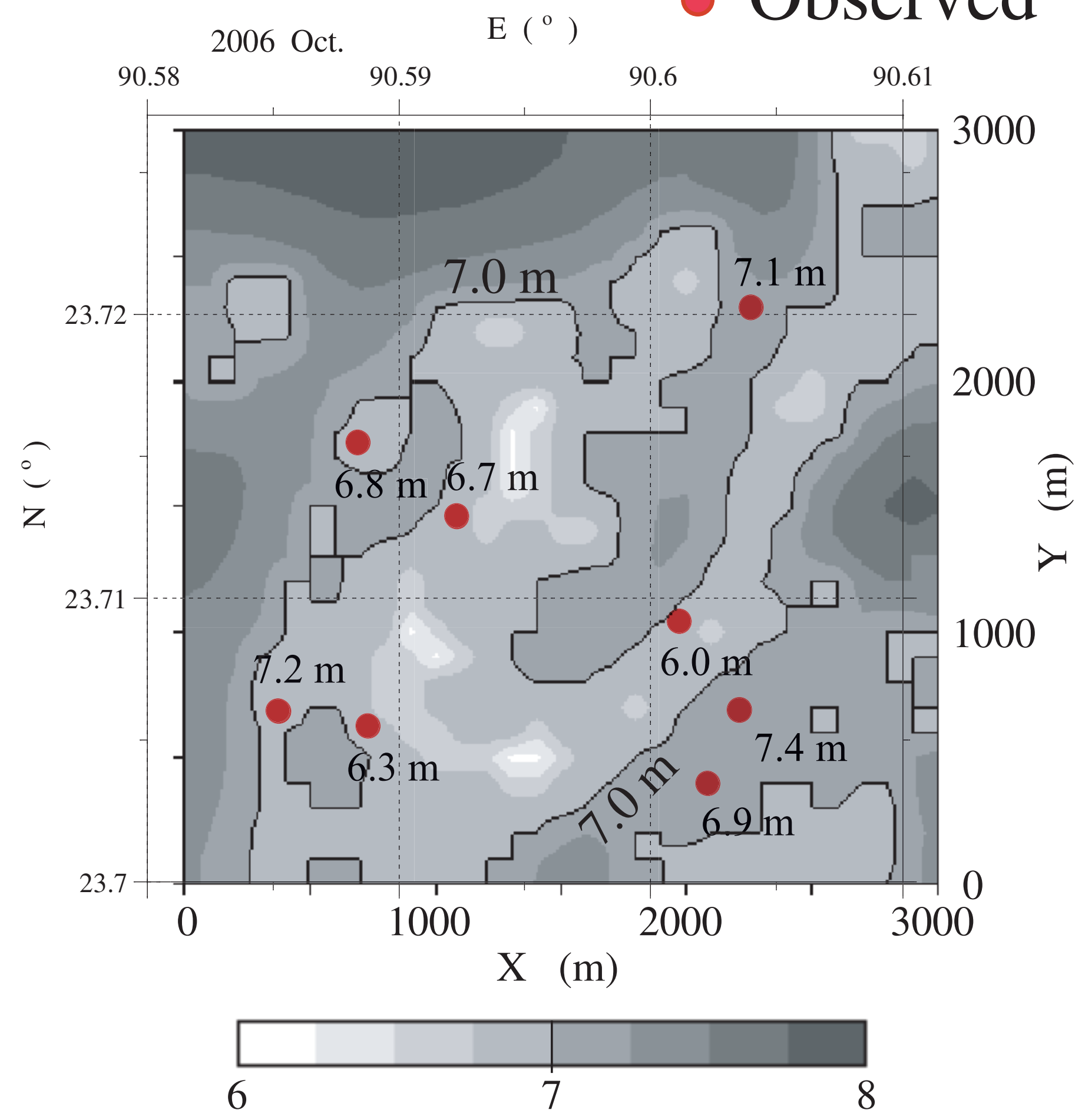

Groundwater table (m ASL)

Figure 7. Contour map of unconfined groundwater head computed for October, early in the dry season, with the observed levels at eight hand-auger drilling sites in early October, 2006. 
(a)

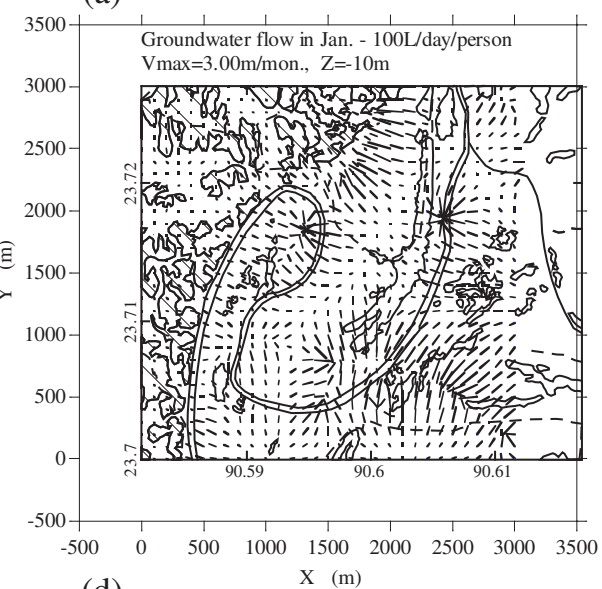

(d)

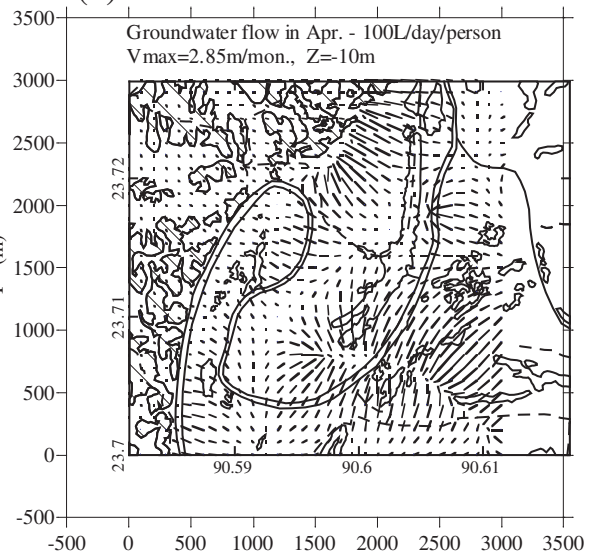

(g)

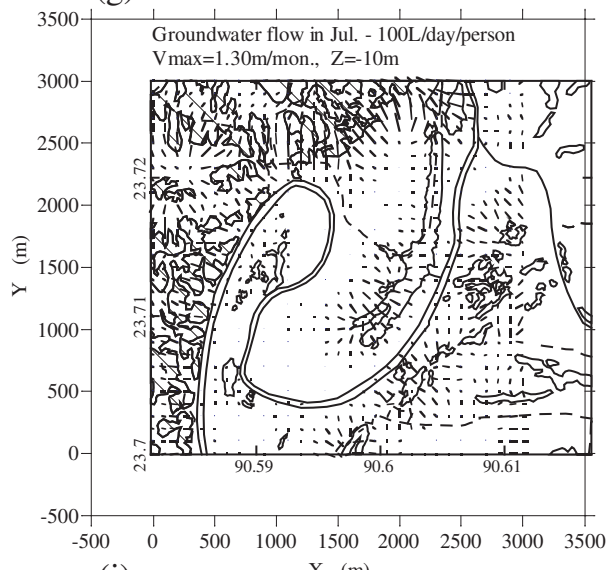

(j)

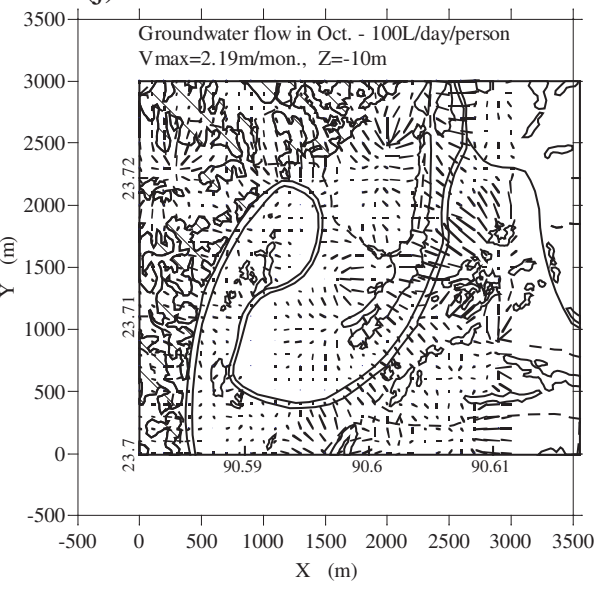

(b)

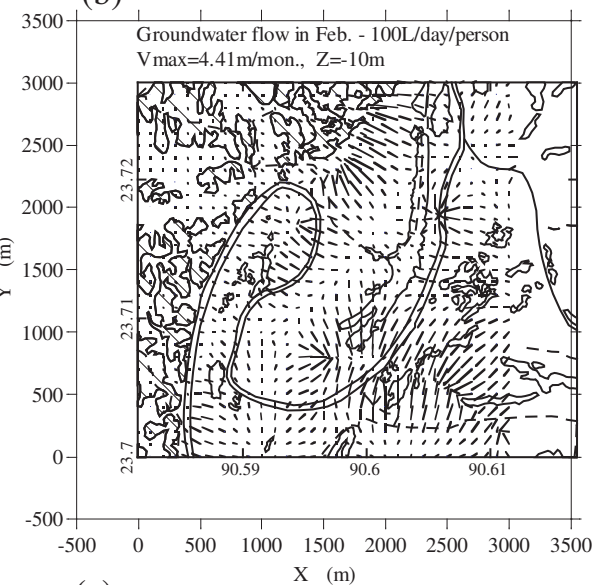

(e)

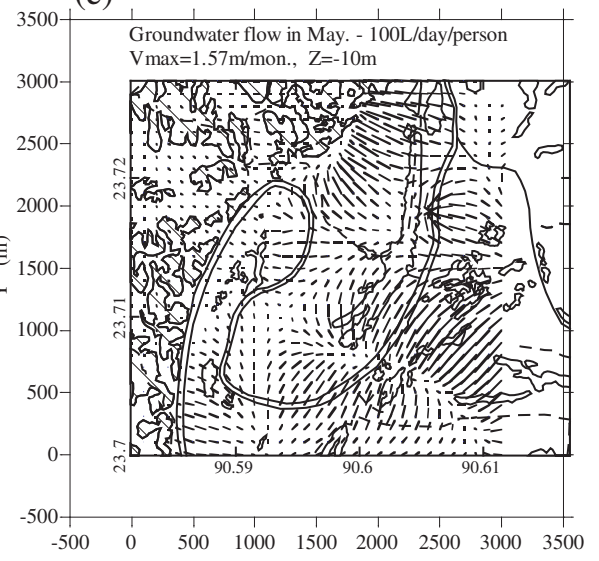

(h)

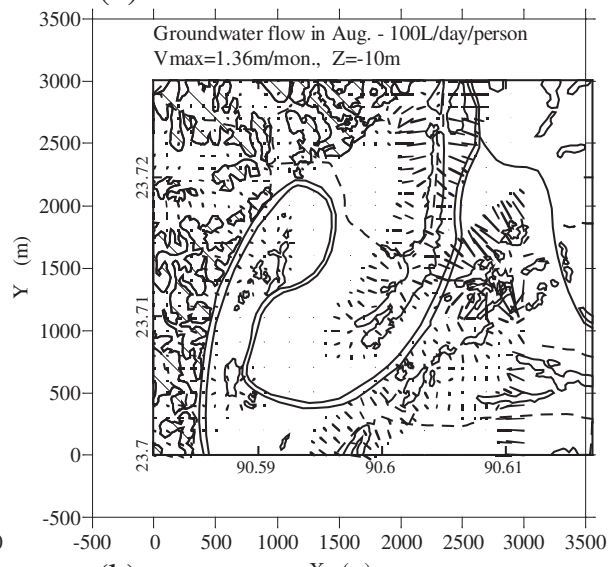

(k)

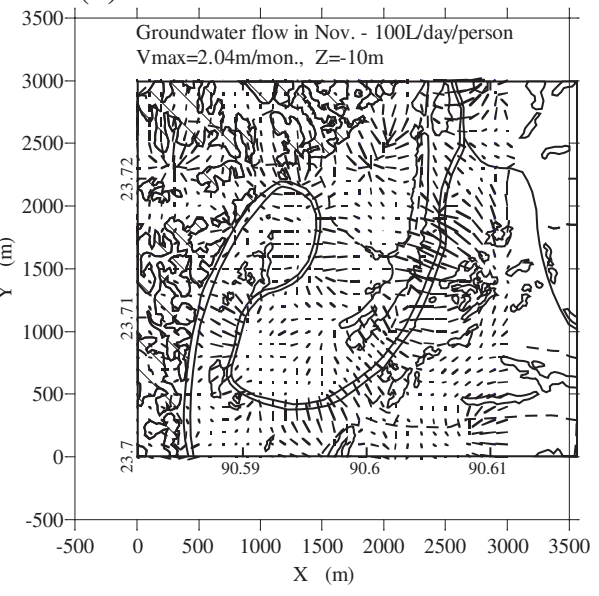

(c)

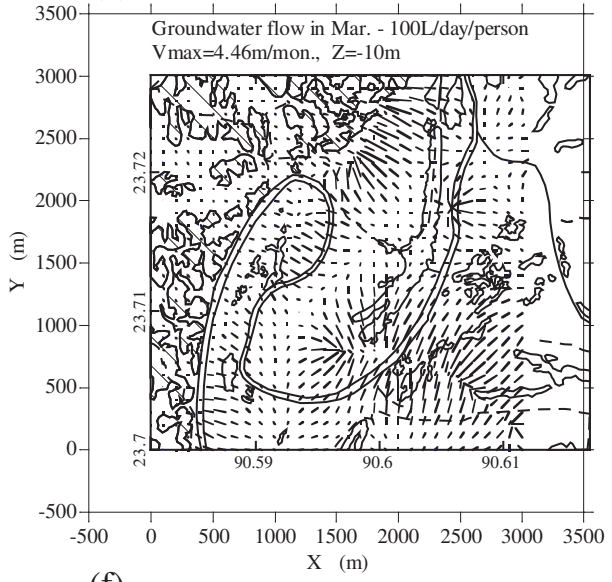

(f)

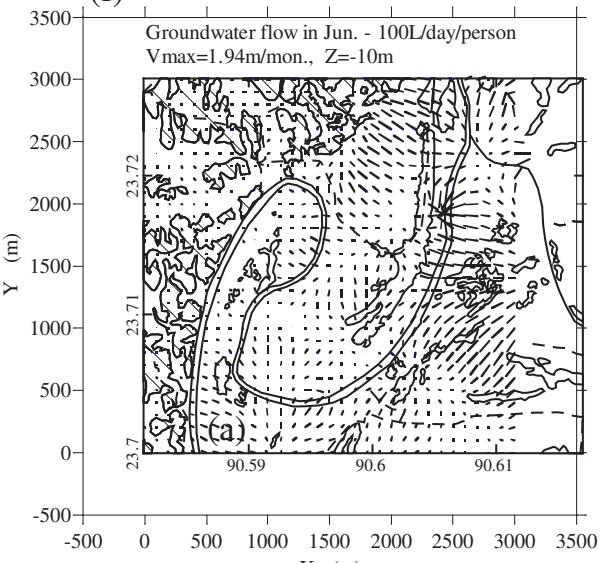

(i)

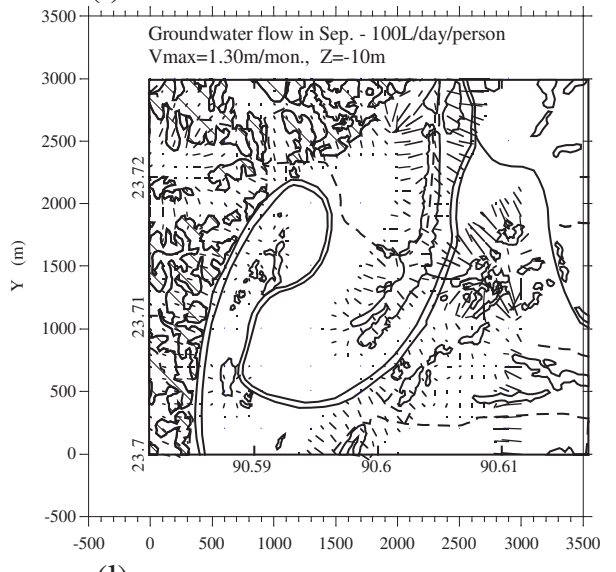

(1)

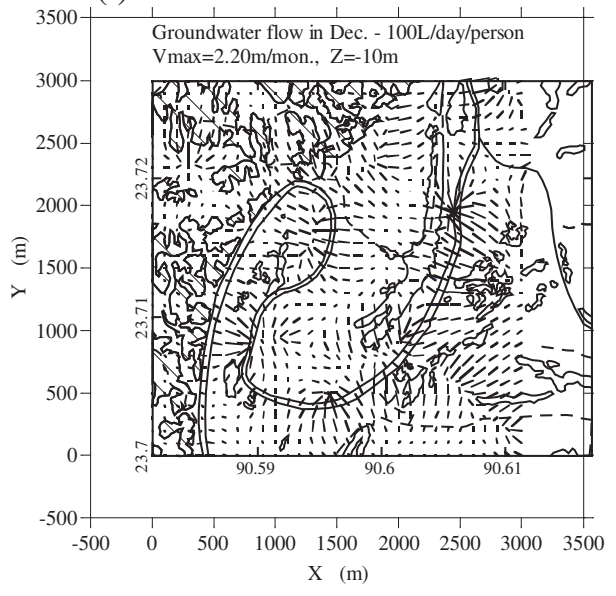

Figure 8. Horizontal groundwater flow velocities simulated at $\mathrm{Z}=-10 \mathrm{~m}$ in January (a), February (b), March (c), April (d), May (e), June (f), July (g), August (h), September (i), October (j), November (k) and December (l). 

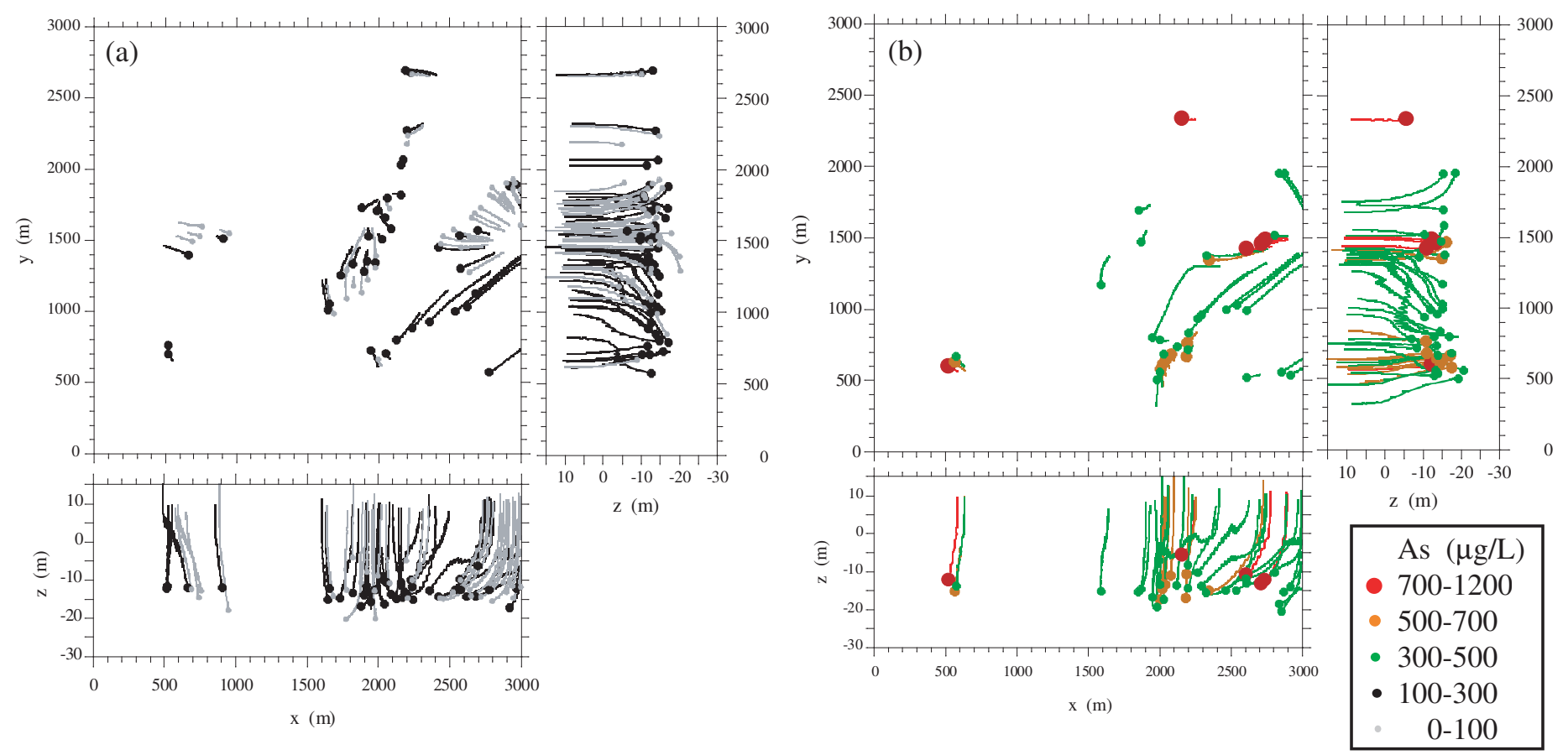

Figure 10. Simulated groundwater flow paths toward the midpoint of the 5-meter long screen, along with As concentrations for the 126 surveyed tube wells installed in the shallow (Holocene) aquifer (above about $-20 \mathrm{~m} \mathrm{ASL}$ ). (a) As $<300 \mu \mathrm{g} / \mathrm{L}$, (b) As $>300 \mu \mathrm{g} / \mathrm{L}$.

Fig. 11, Nakaya et al.

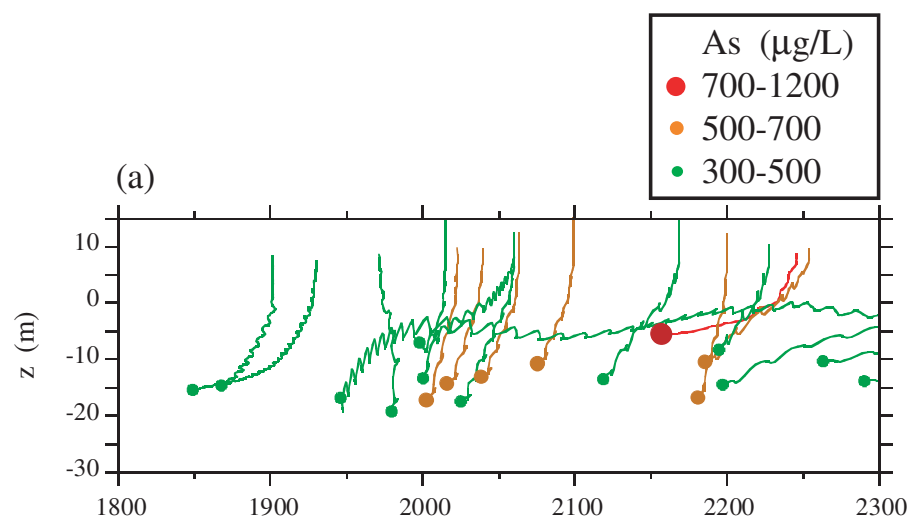

(b)

$\mathrm{x}(\mathrm{m})$

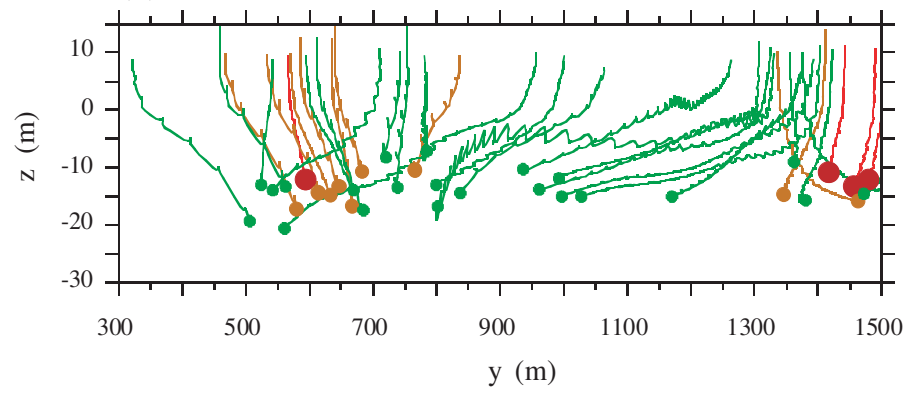

Figure 11. Vertical profile of simulated groundwater flow paths toward the midpoint of the 5-meter long screen, along with As concentrations for the 126 surveyed tube wells installed in the shallow (Holocene) aquifer (above about 20m ASL). (a) $x-z$ plane, (b) $y-z$ plane. 
Fig. 12, Nakaya et al.

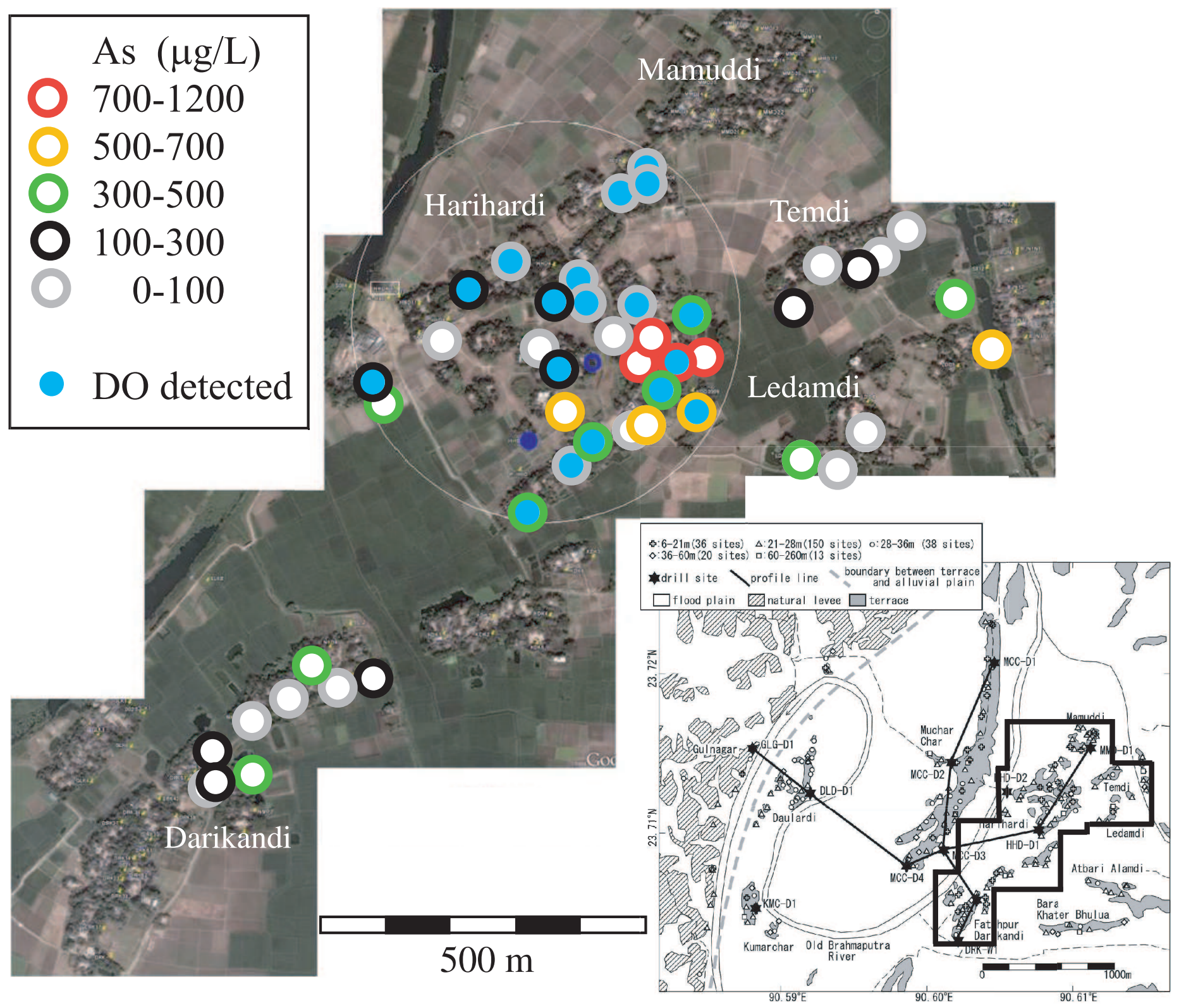

Figure 12. Spatial distribution of As and the concentration of dissolved oxygen (DO) of 45 of the total 51 points measured from the end of September to early November in 2009 in eastern levees where a recharge zone appears. 
Fig. 13, Nakaya et al.

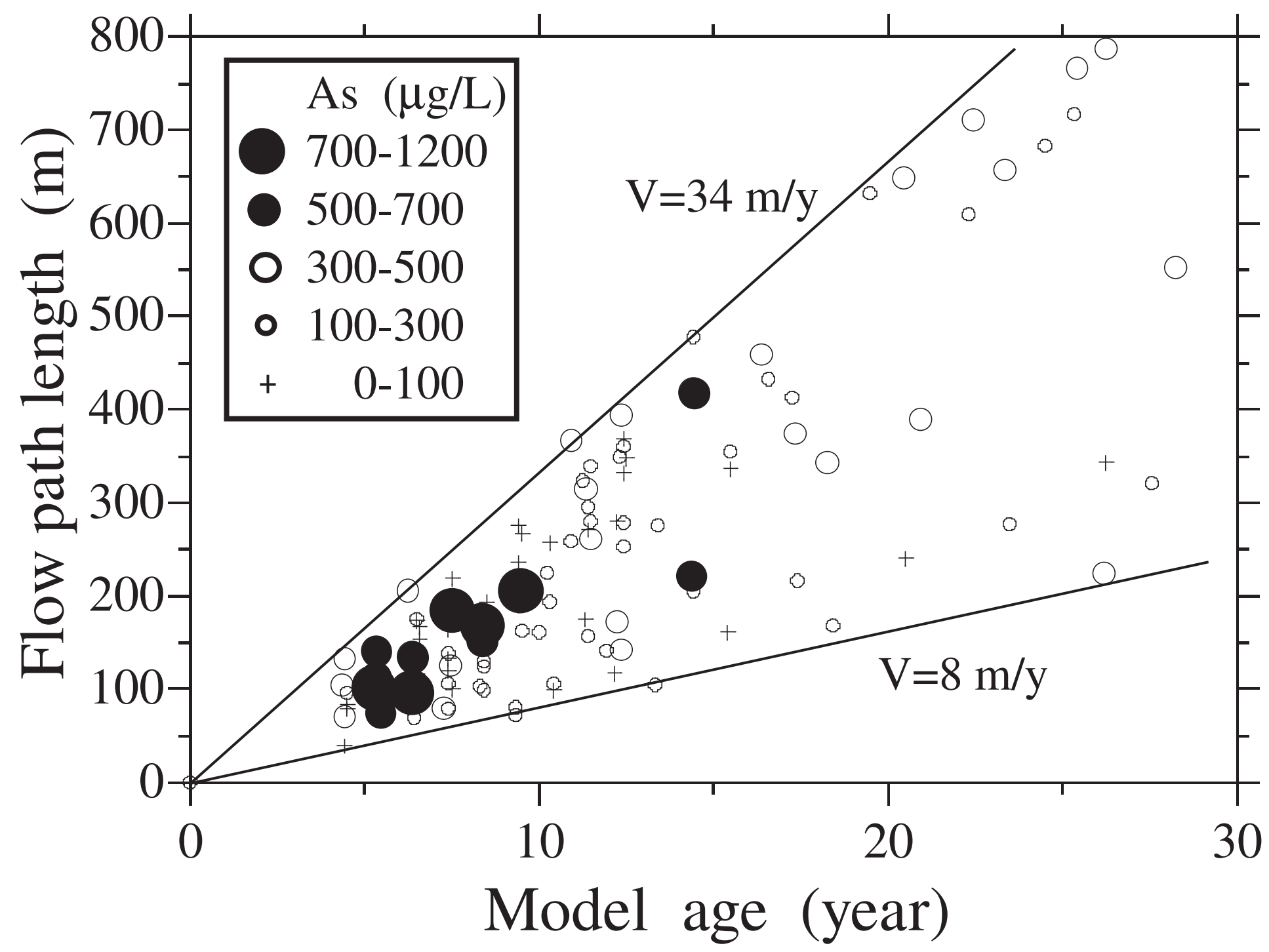

Figure 13. Relationship between the average length of the groundwater flow path (Lp) and the average residence time

(model age) (TR) from the ground surface to tube wells, with the As concentration of each well's water, excluding three wells that had residence times $>30$ years $(920 \mathrm{~m}, 38.5$ years, $351 \mathrm{As} \mu \mathrm{g} / \mathrm{L})$, (367 m, 43 yeas, $146 \mathrm{As} \mu \mathrm{g} / \mathrm{L})$ and $(532 \mathrm{~m}, 31$ years, $75 \mathrm{As}$ $\mu \mathrm{g} / \mathrm{L}) . \mathrm{V}$ indicates velocity by $\mathrm{Lp} / \mathrm{T}_{\mathrm{R}}$. 
Fig. 14, Nakaya et al.

(a)

Ground surface

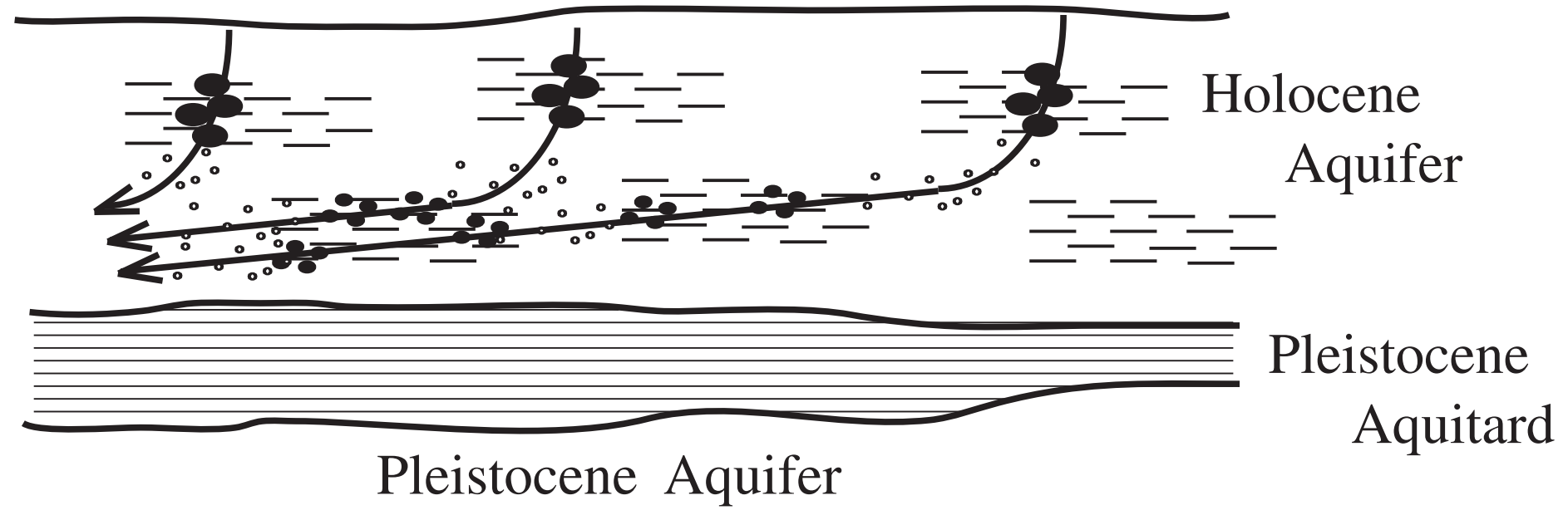

(b)

Ground surface

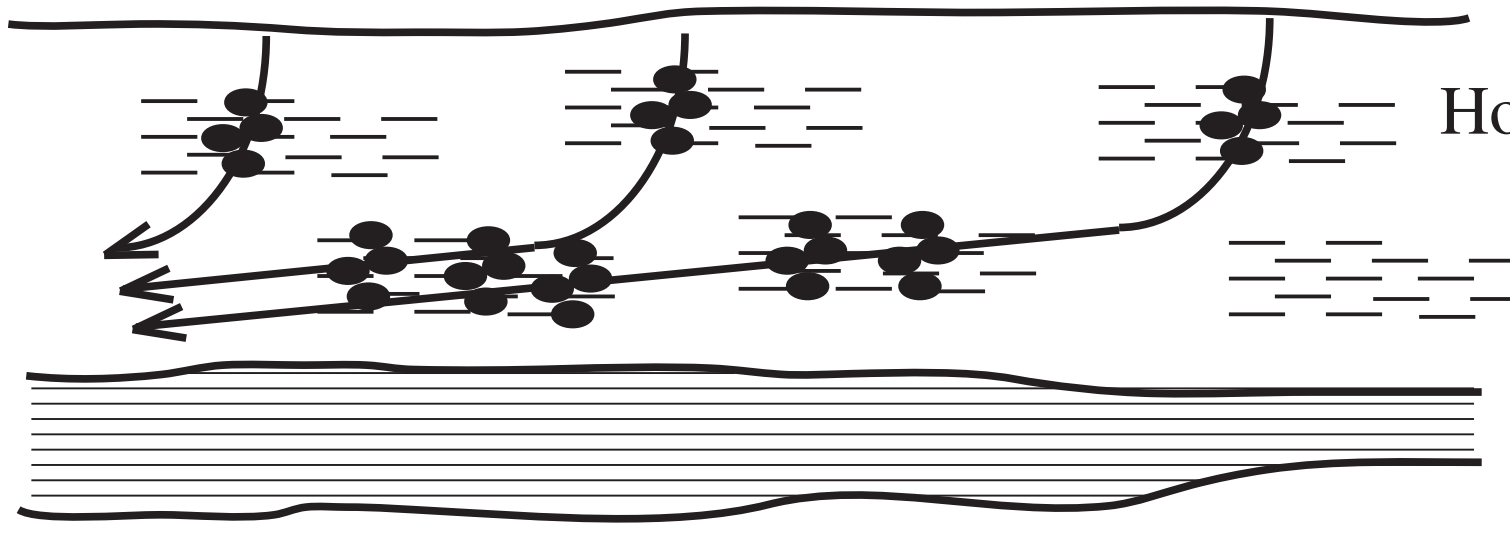

Pleistocene Aquifer

Pleistocene

Aquitard

Aquifer

$\bar{E}=\bar{二}=$ As-rich sediment

$\&$ As release (major) $\quad \therefore \therefore$ Dilution
$\therefore$ As release (minor or not)

Figure 14. (a) Conceptual model A (CM-A) and (b) conceptual model B (CM-B) for As release in the groundwater flow system obtained in this study. 